\title{
O componente "custo de oportunidade" do spread bancário no Brasil: uma abordagem pós-keynesiana ${ }^{1}$
}

\author{
Giuliano Contento de Oliveira ${ }^{2}$ \\ Carlos Eduardo Carvalho ${ }^{3}$
}

\section{Resumo}

A redução pronunciada do spread bancário no Brasil requer a diminuição do custo de oportunidade das operações de crédito no país, representado pelos retornos monetários e não monetários dos títulos públicos federais. Ao permitir a estruturação de uma postura operacional flexível e rentável ao mesmo tempo, esses ativos criam uma disfuncionalidade no mercado de crédito, vez que os bancos passam a exigir um prêmio de risco muito elevado para a concessão de recursos, elevando o spread bancário e aumentando o custo do dinheiro no país.

Palavras-chave: Bancos - Brasil; Crédito bancário; Títulos públicos; Taxa de juros.

\section{Abstract \\ The "opportunity cost" component of bank interest spread in Brazil a post-Keynesian perspective}

The pronounced reduction of the bank interest spread in Brazil requests the decrease of the cost of opportunity of the credit operations in the country, represented by the monetary and no-monetary returns of the federal public titles. When allowing the structuring of a flexible and profitable operational posture at the same time, those assets create an anomaly in the credit market, because the banks start to demand a premium of very high risk for the concession of credit, elevating the bank interest spread and increasing the cost of the money in the country.

Key-words: Bank interest spread; Banks; Credit; Federal public titles; Opportunity cost; Interest rate.

JEL E43, E51, G21, G38.

(1) Trabalho recebido em abril de 2006 e aprovado em abril de 2007. O artigo é uma versão reduzida e aperfeiçoada da dissertação de mestrado defendida por Giuliano C. Oliveira no Programa de Estudos Pósgraduados em Economia Política da Pontifícia Universidade Católica de São Paulo - PUC/SP, em maio de 2004, sob orientação de Carlos E. Carvalho. Agradecemos os comentários e sugestões de Maria Cristina Penido de Freitas, Carlos Kawall Leal Ferreira e dos colegas presentes ao seminário do Grupo de Pesquisa em Moeda e Crédito, da PUC/SP, em 13 de maio de 2003, em que foi apresentada a primeira versão do trabalho. O Professor José Benedito de Zarzuela Maia prestou inestimável ajuda na apuração de alguns dados. Agradecemos pelos comentários e sugestões dos pareceristas anônimos desta revista. Erros e omissões na versão final são de nossa responsabilidade.

(2) Doutorando em Economia no Instituto de Economia da Universidade Estadual de Campinas (IE/Unicamp), São Paulo, Brasil. E-mail: <giulianoliveira@uol.com.br>.

(3) Doutor em Economia pelo IE/Unicamp e Professor do Departamento de Economia da PUC/São Paulo, Brasil. E-mail: <cecarv@uol.com.br>.

Economia e Sociedade, Campinas, v. 16, n. 3 (31), p. 371-404, dez. 2007. 


\section{Introdução}

Os níveis excepcionalmente elevados dos spreads bancários no Brasil têm sido objeto de análise e de iniciativas das autoridades econômicas, diante dos seus efeitos negativos sobre a expansão do crédito e sobre as condições financeiras das empresas do setor produtivo. Essa anomalia observada no mercado de crédito brasileiro se faz sentir de forma notável sob a forma de baixa relação crédito/PIB, seja na comparação com economias do mesmo porte, seja em relação às economias desenvolvidas.

A correção dessa distorção constitui condição fundamental para a retomada do crescimento econômico sustentado no Brasil. A inexistência de um mercado de capitais forte no país, ${ }^{4}$ ao tornar o crédito bancário a principal fonte de financiamento externo para as empresas, ${ }^{5}$ atua no sentido de potencializar os efeitos negativos acarretados pela prática de juros e spreads bancários elevados, reprimindo a transformação das idéias inovadoras dos empresários em realidade objetiva de investimento e, ao cabo, obstaculizando a dinâmica do ciclo de negócios da economia (BID, 2005).

Estudos relacionados ao tema apontam diversos fatores para a prática de altos spreads bancários no país, mas atenção insuficiente tem sido dada aos efeitos da prática de alta taxa básica de juros sobre o diferencial cobrado pelos bancos entre as suas taxas de aplicação e captação de recursos. $\mathrm{O}$ objetivo deste artigo é discutir o aqui denominado componente "custo de oportunidade" do spread bancário no Brasil. Mais do que buscar uma explicação geral para os elevados níveis das margens cobradas pelos bancos no país, o propósito do artigo é destacar mais um de seus fatores explicativos, desconsiderado ou considerado de forma insuficiente pela maior parte da literatura sobre o tema.

Sustenta-se que, além de implicar maior risco de inadimplência nas operações de empréstimos, a prática de altas taxas básicas de juros, ao tornar a aplicação em títulos públicos muito atrativa para os bancos, faz com que o custo de oportunidade envolvido nas operações de crédito seja também muito elevado. Isso faz com que os bancos embutam um prêmio de risco suplementar nas margens cobradas para a concessão de empréstimos, além de aumentarem o grau de exigências junto aos mutuários, seja sob a forma de colaterais, seja de prazo de

(4) É importante notar, no entanto, que a maior estabilidade macroeconômica e a alta dos preços dos ativos promoveram um crescimento do mercado de capitais no período recente. No mais, vale salientar que enquanto o spread bancário no Brasil toma por base as operações com recursos livres, o papel do crédito bancário para as empresas não se resume ao crédito livre, em face da existência de crédito com recursos direcionados, notadamente os empréstimos do BNDES.

(5) Financiamento externo no sentido de não corresponder à obtenção de recursos a partir de lucros acumulados pelas empresas, não no sentido de constituir financiamento a partir de captação de recursos no mercado externo. 
pagamento, já que terão como base o retorno obtido a partir da aquisição de papéis do governo, ativos de risco quase nulo e liquidez e remuneração elevadas.

$\mathrm{O}$ artigo está dividido em seis partes, incluindo esta introdução e a conclusão. Na seção 1, discorre-se sobre o comportamento dos bancos em economias monetárias da produção a partir do referencial pós-keynesiano, que servirá de amparo teórico à hipótese sustentada. A seguir, analisa-se o nível e a trajetória dos spreads cobrados pelos bancos no país, chamando atenção para os patamares excepcionalmente elevados das margens cobradas por essas instituições em suas operações de empréstimos à luz da experiência internacional. Na terceira seção, discorre-se sobre os componentes do spread bancário no Brasil, considerados nos estudos realizados pelo Banco Central sobre o tema. $\mathrm{Na}$ seção 4, discute-se o aqui denominado componente custo de oportunidade do spread bancário, atribuindo destaque à distorção gerada pela prática de elevada taxa básica de juros sobre o mercado de crédito, em particular sobre as margens cobradas pelos bancos em seus empréstimos. Finalmente, na última parte são realizadas as considerações finais.

\section{0 comportamento dos bancos em economias monetárias da produção}

Os bancos não são agentes passivos subordinados às preferências de seus depositantes e às determinações das autoridades monetárias. ${ }^{6}$ A postura operacional dessas instituições é fortemente influenciada pelas expectativas dos próprios banqueiros em relação ao cenário econômico futuro, percepção que será resultante de um conjunto de expectativas composto por fatores objetivos e subjetivos. Keynes (1930a, p. 23) apresentou esse fenômeno, de forma um tanto irônica, do seguinte modo:

Thus the behaviour of each bank, though it cannot afford to move more than a step in advance of the others, will be governed by the average behaviour of the banks as a whole - to which average, however, it is able to contribute its quota small or large. Each bank chairman sitting in his parlour may regard himself as the passive instrument of outside forces over which he has no control; yet the 'outside forces' may be nothing but himself and his fellow-chairmen, and certainly not his depositors (grifo nosso).

Numa economia monetária da produção, o portfólio do banco estará sujeito a mudanças permanentes, e sua composição será expressão de sua escala de preferência por liquidez em dado momento. A escolha de ativos pelos bancos se dará num contexto onde previsões baseadas em cálculos de probabilidades não são

(6) Os bancos criam depósitos contra si próprios, de forma endógena. Um banco concede crédito mediante o lançamento da quantia emprestada no ativo, sob a rubrica "operações de crédito", e no passivo, sob a rubrica "depósito à vista". Nesse movimento, o banco expandiu os meios de pagamento disponíveis na economia por meio da criação de moeda escritural. O depósito criado pelo banco contra si próprio foi denominado por Keynes (1930a, p. 21) como "criação ativa de depósitos". 
suficientes para garantir que o cenário esperado seja aquele efetivamente verificado no período vindouro. Isso ocorre porque numa economia onde o prêmio de liquidez $z^{7}$ de um bem (a moeda), cujas elasticidades de produção e substituição são desprezíveis, é superior ao seu custo de manutenção, movimentos imprevistos podem ocorrer em razão de mudanças bruscas por sua demanda, gerada pelas oscilações do nível geral de expectativas. Estas últimas, cumpre reiterar, são formadas num ambiente de incerteza.

Diferentemente da teoria da preferência por liquidez apresentada no Capítulo 15 da Teoria Geral (Keynes, 1936, p. 139-147), onde o agente opta ou pela liquidez absoluta (moeda) ou pelo prêmio por sua renúncia (juros dos títulos), no Capítulo 17 da referida obra Keynes (1936, p. 157-169) desenvolveu o que passou a ser chamado pela corrente pós-keynesiana de "teoria da composição da carteira e da precificação de ativos", uma maneira alternativa, não dicotômica e, portanto, mais completa de interpretar a teoria da preferência por liquidez elaborada por Keynes (1936).

Doravante a liquidez passa a ser entendida como uma questão de grau, ${ }^{8}$ onde retornos monetários e não monetários (prêmio de liquidez) podem ser combinados numa classe ou num conjunto de ativos. O mundo dicotômico onde existem somente dois tipos de ativos, moeda e títulos, cede lugar a um mundo onde existe uma diversidade de ativos que apresentam diferentes níveis de liquidez e rentabilidade e que podem ser combinados de várias maneiras (Carvalho, 1999).

O retorno total oferecido por um ativo corresponderá aos valores assumidos por quatro atributos, denominados por Keynes (1936, p. 159-160) de: a) apreciação ou depreciação do valor de mercado do ativo, “ $a$ "; b) taxa de rendimento que se espera obter pelo uso ou pela posse de um ativo, " $q$ "; c) custo de manutenção ou carregamento do ativo, “c” e; d) prêmio de liquidez do ativo, que corresponde ao rendimento monetário de que as pessoas abrem mão em razão da conveniência ou segurança oferecida pela liquidez, “l”, ou como diz Keynes (1936, p.159), componente da taxa específica de juros de um ativo que se refere "[...] ao montante [...] que as pessoas estão dispostas a pagar pela conveniência ou segurança potenciais pelo poder de dispor dele [...]". Desse modo, a taxa de juros própria de cada classe de ativos pode ser apresentada a partir da seguinte equação:

$$
a+q-c+l
$$

(7) O prêmio de liquidez de um ativo, também chamado de retorno não monetário, corresponde ao rendimento monetário sacrificado pelo agente em prol da conveniência ou segurança oferecida pelo atributo liquidez. Isso ocorre porque numa economia monetária da produção, onde prevalece a incerteza não probabilística, quanto maior a facilidade de um ativo ser convertido em moeda (a própria liquidez), maior proteção será oferecida ao seu detentor.

(8) De acordo com Keynes (1936, p. 166), “[...] talvez seja útil insistir sobre o fato [...] de que a 'liquidez' e os 'custos de manutenção' são, ambos, questão de grau e que é unicamente na importância da primeira em relação aos últimos que reside a peculiaridade da moeda". 
É a partir da combinação desses atributos que os bancos irão conformar os seus respectivos portfólios. O grau de preferência entre retornos monetários forma alternativa de se designar o prêmio de liquidez de um ativo -, sob a forma de rendimentos $(\boldsymbol{q}-\boldsymbol{c})$ ou ganhos de capital $(\boldsymbol{a})$, e não monetários $(\boldsymbol{l})$, irá depender das expectativas dessas instituições em relação ao futuro, ${ }^{9}$ cuja formação será estruturada num ambiente de incerteza (Keynes, 1930a; 1930b; 1936). Disso resulta que as decisões dos bancos serão tomadas à luz do trade-off retornos monetários versus não monetários.

No que compete ao lado esquerdo do balanço, numa economia monetária da produção, o dilema do banqueiro será a proporção sob a qual ele irá dividir seus recursos entre os diferentes tipos de ativos disponíveis, mais ou menos líquidos, e não quanto ele irá emprestar no agregado. Sua preocupação, portanto, corresponderá ao grau de liquidez de sua carteira de ativos, a qual será mais ou menos líquida a depender de sua percepção de incerteza em relação ao futuro. A esse respeito, Keynes (1930b, p.59) fez a seguinte afirmação:

[...] what bankers are ordinarily deciding is, not how much they will lend in the aggregate - this is mainly settled for them by the state of their reserves - but in what forms they will divide their resources between the different kinds of investment which are open to them. Broadly there are three categories to choose from - (i) bills of exchange and call loans to the money market, (ii) investments, (iii) advances to customers. As a rule, advances to customers are more profitable than investments, and investments are more profitable than bills and call loans; but this order is not invariable. On the other hand, bills and call loans are more 'liquid' than investments, i.e. more certainly realisable at short notice without loss, and investments are more 'liquid' than advances [...] the proportions in which their resources are divided between these three categories suffer wide fluctuations [...] (grifo nosso).

Isso significa que os bancos podem combinar diversos ativos com diferentes atributos, tais como prazos de maturação, níveis de liquidez e rentabilidade, num mesmo portfólio. Nesse sentido, a oferta de crédito não será determinada passivamente pela demanda. Na abordagem da teoria da preferência por liquidez, em contraposição à perspectiva horizontalista, ${ }^{10}$ a demanda por crédito será satisfeita apenas se os banqueiros assim o desejarem, caso as suas expectativas em relação à capacidade de pagamento futuro dos empréstimos pelos

(9) Todos os ativos existentes na economia devem necessariamente possuir a mesma taxa de juro própria de equilíbrio ex ante, uma vez que o processo de arbitragem atua no sentido de mitigar as possíveis diferenças entre o retorno de diferentes ativos. Portanto, sendo os ativos i e j, a condição de equilíbrio será dada por: ai + qi $-\mathrm{ci}+\mathrm{li}=\mathrm{aj}+\mathrm{qj}-\mathrm{cj}+\mathrm{lj}$, para todo e qualquer i e j (Carvalho et al., 2000).

(10) Na perspectiva horizontalista, a oferta de moeda é completamente endógena, onde os bancos são meros transferidores de recursos sob uma determinada taxa de juros. A oferta de moeda é, portanto, horizontal no espaço juros versus recursos emprestados. Para uma análise crítica desta abordagem, ver Freitas (1999). 
mutuários e à manutenção do valor do colateral forem otimistas e se a natureza das obrigações emitidas assim o permitir (Carvalho, 1999).

Nesse sentido, tanto a oferta de crédito, quanto a sua taxa de juros, além de depender do risco de crédito do mutuário, da existência de colaterais, da natureza das obrigações emitidas ${ }^{11}$ e da necessidade de recursos para satisfazer os compromissos com os depositantes sob condições adversas, será dependente dos retornos monetários e não monetários de outras classes de ativos. Nas palavras de Carvalho (1999, p. 11) sobre a oferta de crédito:

It would rather depend on each bank's assessments not only of the specific credit risks each borrower represented, but also on the nature of the liabilities issued by the bank, the need to be ready to meet the contractual cash outflows even under adverse conditions and the own-rates of interest of the other classes of assets (grifo nosso).

Decorre que a existência de classes de ativos que oferecem retornos monetários e não monetários atrativos pode criar uma disfuncionalidade no mercado de crédito. Em contextos sob os quais as operações de empréstimos apresentam risco muito elevado, a taxa de juros própria dos ativos mais seguros e líquidos irá representar o custo de oportunidade das operações de crédito. Quanto mais essa taxa for atrativa, mais essas instituições estarão dispostas a estabelecer um prêmio de risco muito alto para a concessão de recursos, condição que concorre na direção de atravancar a expansão do crédito e obstaculizar a retomada do crescimento sustentado da economia.

\section{Nível e trajetória do spread bancário no Brasil}

Esperava-se que a transição para o ambiente de inflação baixa no Brasil, ao reduzir drasticamente as receitas obtidas pelos bancos com a alta inflação, atuaria no sentido de induzi-los a operar com maior agressividade no mercado de crédito, inclusive com spreads e juros mais baixos que no período de alta inflação. Todavia, observou-se quadro distinto: além de não aumentarem de forma duradoura os empréstimos no período posterior à queda da inflação, os bancos praticaram juros e spreads muito elevados durante todo esse interregno, obstaculizando o adensamento das relações de crédito e débito da economia e reduzindo seu papel no processo de dinamização do ciclo de negócios.

(11) Tão importante quanto a composição do portfólio do banco é a forma pela qual a compra dos ativos é financiada. Numa economia monetária da produção, a decisão estratégica de balanço do banco será procedida com base na escolha entre quanto e quais tipos de ativos comprar e quanto e quais tipos de obrigações emitir, escolha esta que será orientada de acordo com a percepção de risco e oportunidades de lucro dos bancos. Isso não significa que a captação de recursos seja uma necessidade prévia para que os bancos emprestem, como admitido pela abordagem tradicional, mas sim que, diante de oportunidades lucrativas, os bancos podem explorar novos canais de financiamento de modo a potencializar determinadas operações ativas. Os bancos não só criam depósitos mediante a emissão de dívidas contra si próprios, como também estão continuamente buscando captar recursos de modo a conformar o seu passivo de acordo com as necessidades de seu ativo. 
Tabela 1

Spread bancário em países desenvolvidos e latino-americanos selecionados, em pontos percentuais (1994 a 2005)

\begin{tabular}{l|r|r|r|r|r|r|r|r|r|r|r|r}
\hline \multicolumn{1}{|c|}{ Países selecionados } & 94 & 95 & 96 & 97 & 98 & 99 & 00 & 01 & 02 & 03 & 04 & 05 \\
\hline Países desenvolvidos (G7) & & & & & & & & & & & & \\
\hline Alemanha & 7,0 & 7,1 & 7,2 & 6,4 & 6,1 & 6,4 & 6,2 & 6,5 & 7,1 & nd & nd & nd \\
\hline Canadá & 2,9 & 3,4 & 3,1 & 3,1 & 3,5 & 3,6 & 3,8 & 3,6 & 3,4 & 3,6 & 3,2 & 2,9 \\
\hline Estados Unidos & 2,5 & 2,9 & 2,9 & 2,8 & 2,9 & 2,7 & 2,8 & 3,2 & 3,0 & 3,0 & 2,8 & 2,7 \\
\hline França & 3,4 & 3,6 & 3,1 & 2,8 & 3,3 & 3,7 & 4,1 & 4,0 & 3,6 & 3,9 & 4,4 & nd \\
\hline Itália & 5,0 & 6,0 & 5,6 & 4,9 & 4,7 & 4,0 & 4,4 & 4,6 & 4,4 & 4,1 & nd & nd \\
\hline Japão & 2,4 & 2,6 & 2,4 & 2,2 & 2,1 & 2,0 & 2,0 & 1,9 & 1,8 & 1,8 & 1,7 & 1,4 \\
\hline Reino Unido & 1,8 & 2,6 & $-0,3$ & $-0,6$ & $-0,3$ & nd & nd & nd & nd & nd & nd & nd \\
\hline América Latina & & & & & & & & & & & & \\
\hline Argentina & 2,0 & 6,0 & 3,2 & 2,3 & 3,1 & 3,0 & 2,8 & 11,6 & 12,4 & 9,0 & 4,2 & 2,4 \\
\hline Bolívia & 37,1 & 32,2 & 36,8 & 35,3 & 26,6 & 23,1 & 23,6 & 10,2 & 11,1 & 6,3 & 7,1 & 11,7 \\
\hline Brasil (a) & - & - & - & 53,8 & 58,4 & 54,4 & 39,6 & 39,8 & 43,7 & 45,1 & 39,5 & 37,8 \\
\hline Brasil (b) & 139,2 & 127,3 & 56,4 & 63,3 & 58,4 & 43,2 & 36,1 & 40,0 & 42,5 & 41,5 & 36,2 & 36,6 \\
\hline Chile & 5,2 & 4,4 & 3,9 & 3,7 & 5,3 & 4,1 & 5,6 & 5,7 & 4,0 & 3,5 & 3,2 & 2,8 \\
\hline Colômbia & 11,1 & 10,4 & 10,8 & 10,1 & 9,7 & 4,4 & 6,6 & 8,3 & 7,4 & 7,4 & 7,3 & 7,6 \\
\hline México & 4,3 & 19,6 & 10,0 & 5,8 & 10,9 & 12,1 & 8,7 & 6,6 & 4,4 & 3,8 & 4,5 & 6,4 \\
\hline Paraguai & 12,4 & 12,8 & 14,7 & 14,8 & 14,5 & 10,5 & 11,1 & 12,0 & 15,8 & 34,2 & 28,4 & 28,3 \\
\hline Peru & 31,2 & 11,5 & 11,2 & 15,0 & 15,7 & 14,5 & 14,6 & 10,5 & 10,5 & 10,4 & 11,5 & 11,5 \\
\hline Uruguai & 33,5 & 35,4 & 43,5 & 37,6 & 31,6 & 28,5 & 27,8 & 27,0 & 55,8 & 29,3 & 17,5 & 10,8 \\
\hline
\end{tabular}

Fonte: IMF (2006); para Brasil (b), adaptado de Banco Central do Brasil (10 abr. 2006). 
A Tabela 1 apresenta o diferencial cobrado pelos bancos entre suas taxas de captação e aplicação de recursos em países desenvolvidos e latino-americanos selecionados, ${ }^{12}$ no período 1994-2005. Pode-se verificar que, nos países desenvolvidos, os spreads bancários são muito inferiores aos praticados nos países da América Latina (AL), exclusive Argentina, até 2001, com o Brasil apresentando o maior spread bancário da região no interregno, perdendo apenas para o Uruguai em 2002. Além disso, mas não menos importante, a diferença entre os níveis de spread no Brasil e nos demais países da AL é bem maior que a diferença entre os níveis dos países do G7 e a maior parte dos países da AL, com exceção apenas do Brasil e de um ou outro que se aproxima do patamar brasileiro em determinados momentos (Bolívia, Argentina e Uruguai). As margens bancárias no Brasil mostram-se sempre muito maiores, tanto em relação aos países do G7, quanto ao nível médio apresentado na AL.

Já a Figura 1 apresenta a trajetória dos spreads médios prefixados cobrados pelos bancos no Brasil em suas operações de crédito com recursos livres no período posterior ao Plano Real. A linha vertical posta sobre o gráfico indica o início da implementação de medidas destinadas à redução das margens bancárias no país, iniciativa levada a cabo no âmbito do projeto "Juros e spread bancário no Brasil", implementado em outubro de 1999, estando em vigor até os dias atuais, cujo objetivo é promover ações que reduzam os custos dos empréstimos bancários realizados com recursos livres (Banco Central do Brasil, 2002).

Os elevadíssimos níveis observados logo após o Plano Real refletiam as medidas de restrição ao crescimento do crédito, que colocava em risco o sucesso do plano de estabilização, como recolhimento compulsório sobre os depósitos à vista, a prazo e de poupança, além da imposição de recolhimento sobre as operações ativas dos bancos e de restrições diversas ao financiamento do consumo implementadas em outubro de 1994. A essas medidas, somava-se a prática de elevada taxa de juros básica da economia (Figura 2), que buscava conter o nível de

(12) Dados obtidos pela diferença entre lending rates (line 60p) e deposit rates (line 601). É importante registrar, contudo, que embora já utilizado em diversos trabalhos sobre o tema, como Afanasieff, Lhacer e Nakane (2001), esse método de cálculo a partir dos dados referenciados carrega algumas distorções a título de comparação internacional, conforme indicado por Laeven e Majnoni (2003) e, mais recentemente, por Nakane e Costa (2005). Isso porque, além das diferenças relevantes entre os diversos sistemas financeiros nacionais, para alguns países as taxas de empréstimos se referem à taxa média praticada junto aos tomadores primários, enquanto para outros se referem à taxa média praticada junto aos tomadores de qualidade média. Laeven e Majnoni (2003) registram ainda que, em países com largo componente de ativos dolarizados, como a Argentina até 2001, torna-se difícil avaliar se as taxas de empréstimos ou depósitos são referenciadas nas taxas em moeda doméstica ou nas taxas que refletem a média das taxas em moeda doméstica e em dólar. Alguns países, ademais, tomam por base apenas operações de crédito selecionadas para o cálculo das taxas de aplicação, como o Brasil, cujos dados tomam por base apenas as operações com recursos livres. Buscando contornar essas anomalias, Nakane e Costa (2005) calcularam o spread para um conjunto selecionado de países pelo índice de Lerner. A partir dessa metodologia, o Brasil deixa de liderar o ranking dos maiores spreads do mundo. Contudo, essa metodologia não exprime o spread bancário em termos absolutos, conforme registrado pelos próprios autores. Nesse sentido, a despeito do avanço metodológico, no Brasil as margens médias cobradas pelos bancos em seus empréstimos continuam sendo as maiores do planeta. 
consumo e atrair recursos externos para financiar o elevado déficit em transações correntes do balanço de pagamentos, vetor que conforme será discutido no decorrer do artigo, configura-se em mais um elemento de pressão sobre as margens cobradas pelos bancos em suas operações de empréstimos (Freitas, 2000).

Figura 1

Spread bancário referencial para a taxa de juros no Brasil (jul. 1994 a dez. 2005)

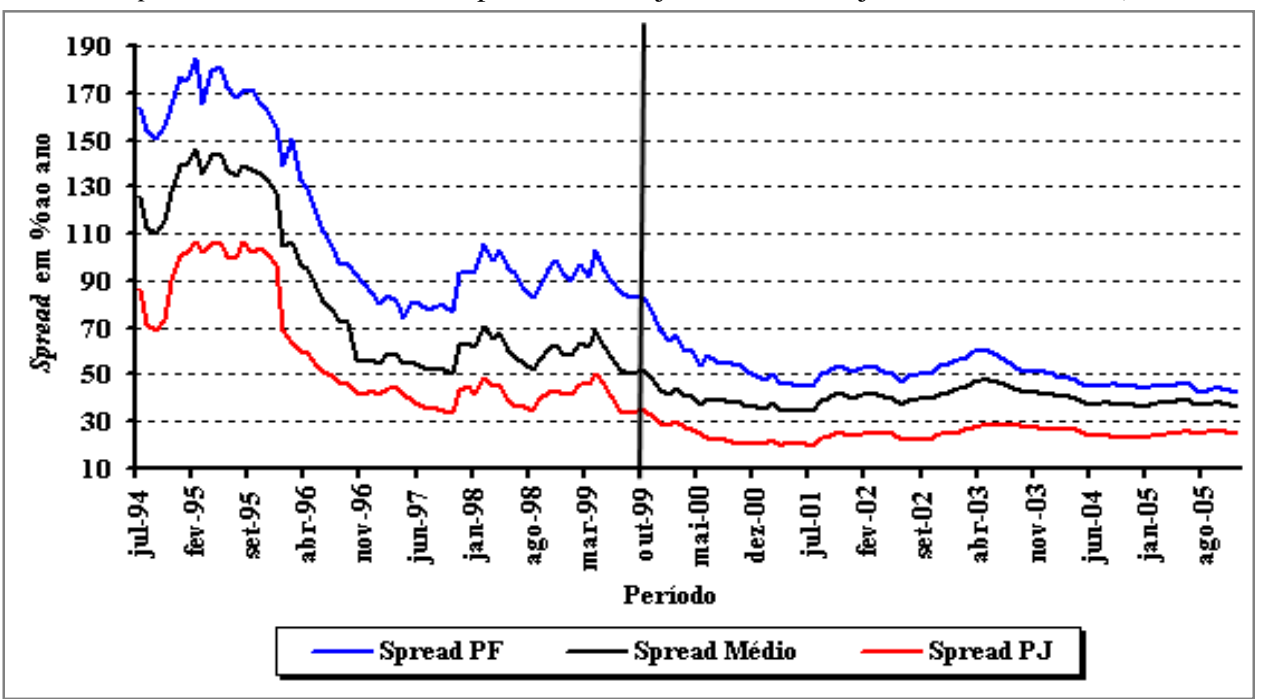

Fonte: Adaptado de Banco Central do Brasil (05 fev. 2006).

Figura 2

Taxa Selic acumulada no mês anualizada (ago. 1994 a dez. 2005)

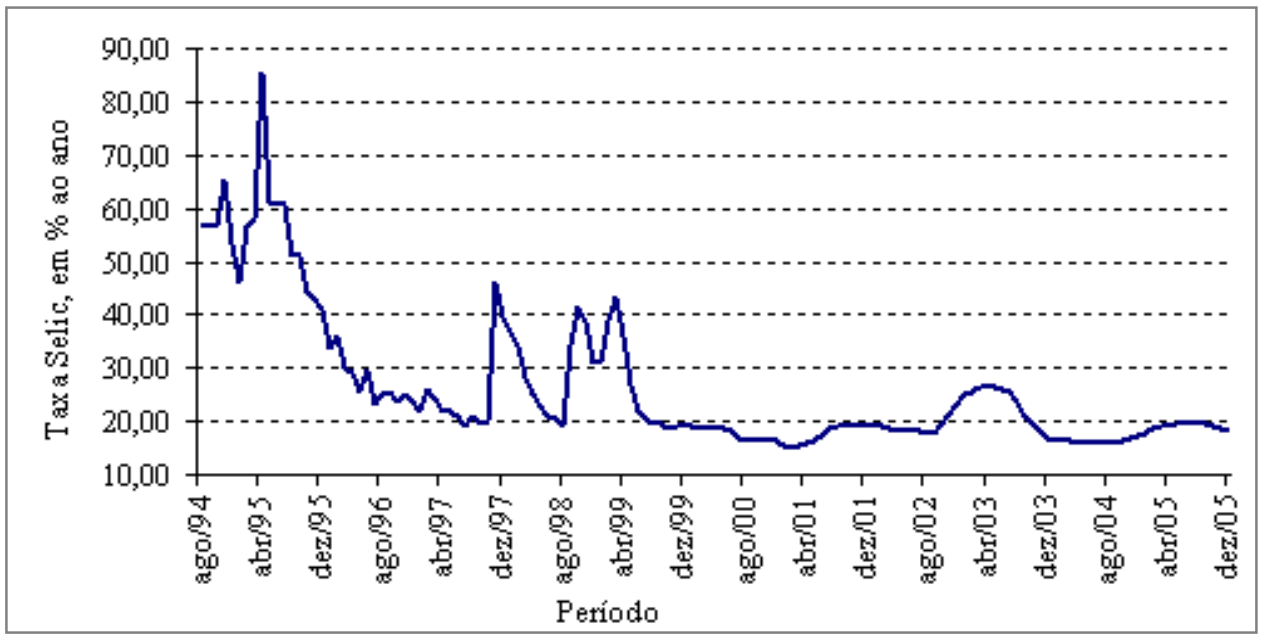

Fonte: Adaptado de Banco Central do Brasil (05 fev. 2006).

A tendência de queda pronunciada das margens cobradas pelos bancos em suas operações de empréstimos só se verificou com a flexibilização da política monetária, a partir do segundo semestre de 1995, possibilitada pela redução da 
desconfiança dos agentes em relação aos desdobramentos da crise mexicana de 1994-1995. Foram realizadas reduções sistemáticas da taxa de juros básica da economia entre o segundo trimestre de 1995 e o final de 1997 (Figura 2), com reversões apenas episódicas e incapazes de reverter a trajetória de queda. ${ }^{13}$ Não menos importante, a partir do segundo semestre de 1995, operou-se a diminuição das alíquotas de recolhimentos compulsórios incidentes sobre os depósitos à vista, a prazo e de poupança, bem como sobre os Fundos de Investimentos Financeiros de 30 dias e sobre as operações de crédito dos bancos, que a partir de novembro de 1995 passa a ser extinto ${ }^{14}$ (Tabela 2).

Observa-se, ademais, que a despeito de os spreads bancários caírem significativamente entre fins de 1995 e de 1997 e, em menor medida, entre meados do primeiro semestre de 1999 e de 2001, as margens cobradas pelos bancos no Brasil em seus empréstimos permanecem em níveis elevadíssimos, seja na comparação com os países desenvolvidos, seja em relação aos spreads praticados nos países da América Latina (Tabela 1).

Cumpre destacar, ainda, que as margens cobradas pelos bancos no Brasil variam de forma significativa entre as diferentes modalidades de crédito, conforme apresentado na Tabela 3. Observam-se desvios entre as modalidades destinadas às pessoas físicas e jurídicas, pactuadas sob encargos prefixados, pós-fixados e flutuantes, bem como entre o mesmo grupo de tomadores e encargos. Os maiores spreads cobrados pelos bancos nas operações com pessoas físicas vis-à-vis empresas podem ser atribuídos, principalmente, a três ordens de fatores, a saber: a) a inadimplência nas operações com pessoas físicas é superior à observada junto às pessoas jurídicas, condição que induz a cobrança de uma margem maior pelos bancos (Fachada; Figueiredo; Lundberg, 2003); b) as empresas, em geral, possuem maior poder de barganha, de escolha e de troca de banco (Koyama; Tonooka, 2002); e c) por conta disso, certamente a extração de "rendas informacionais" é muito superior no caso das pessoas físicas, do que no caso das empresas ${ }^{15}$ (Koyama; Tonooka, 2002).

(13) Este processo indica a suscetibilidade do spread cobrado pelos bancos em seus empréstimos às mudanças dos juros básicos estipulados pela autoridade monetária, relação que será discutida adiante.

(14) O compulsório sobre o FIF 60 dias, instituído em julho de 1995, foi zerado já em agosto daquele ano. Apenas o recolhimento sobre o FIF de curto prazo escapou à regra geral e passou de $35 \%$ em julho de 1995 , quando foi instituído, para $40 \%$ em agosto do mesmo ano. Não menos importante, cumpre destacar que os recolhimentos incidentes sobre as operações de crédito e sobre os FIFs tiveram as respectivas alíquotas zeradas, em diferentes momentos. Desse modo, desde agosto de 1999 vigoram no Brasil recolhimentos apenas sobre os depósitos à vista, a prazo e de poupança.

(15) A posse das informações relacionadas ao desempenho passado de seus clientes (inside information) permite que os bancos desfrutem de poder de monopólio a posteriori, isto é, mesmo em mercados de crédito altamente competitivos previamente à concessão do empréstimo. O monopólio da informação faz com que, em vez de baixar o custo do crédito, os bancos se apropriem de lucros extraordinários de seus melhores clientes, mesmo oferecendo-lhes a melhor proposta do mercado. Isso ocorre porque o banco não repassa o menor risco de default envolvido na operação para os seus mutuários de alta qualidade. Num mundo com distribuição simétrica de informação isso não ocorreria, pois os outside banks ofereceriam taxas de juros menores do que as praticadas pelos inside banks (Sharpe, 1990). 
Tabela 2

Alíquotas de recolhimento sobre encaixes obrigatórios - 1994 a 2005, em \%

\begin{tabular}{|c|c|c|c|c|c|c|c|}
\hline Período & $\begin{array}{c}\text { Recursos à } \\
\text { vista }^{1,2}\end{array}$ & $\begin{array}{c}\text { Depósitos a } \\
\text { prazo }^{1}\end{array}$ & $\begin{array}{c}\text { Depósitos de } \\
\text { Poupança }^{1}\end{array}$ & $\begin{array}{c}\text { Operações de } \\
\text { crédito }\end{array}$ & $\begin{array}{c}\text { FIF curto } \\
\text { prazo }\end{array}$ & FIF 30 dias & FIF 60 dias \\
\hline Antes do Plano Real & 50 & - & 15 & - & - & - & - \\
\hline 1994 Jun. & 100 & 20 & 20 & - & - & - & - \\
\hline Ago. & $"$ & 30 & 30 & - & - & - & - \\
\hline Out. & $"$ & $"$ & $"$ & 15 & - & - & - \\
\hline Dez. & 90 & 27 & $"$ & $"$ & - & - & - \\
\hline 1995 Abr. & $"$ & 30 & $"$ & $"$ & - & - & - \\
\hline Maio & $"$ & $"$ & $"$ & 12 & - & - & - \\
\hline Jun. & $"$ & $"$ & $"$ & 10 & - & - & - \\
\hline Jul. & 83 & $"$ & $"$ & $"$ & 35 & 10 & 5 \\
\hline Ago. & $"$ & 20 & 15 & 8 & 40 & 5 & 0 \\
\hline Set. & $"$ & $"$ & $"$ & 5 & $"$ & $"$ & $"$ \\
\hline Nov. & $"$ & $"$ & $"$ & 0 & $"$ & $"$ & $"$ \\
\hline 1996 Ago. & 82 & $"$ & $"$ & $"$ & 42 & $"$ & $"$ \\
\hline Set. & 81 & $"$ & $"$ & $"$ & 44 & $"$ & $"$ \\
\hline Out. & 80 & $"$ & $"$ & $"$ & 46 & $"$ & $"$ \\
\hline Nov. & 79 & $"$ & $"$ & $"$ & 48 & $"$ & $"$ \\
\hline Dez. & 78 & $"$ & $"$ & $"$ & 50 & $"$ & $"$ \\
\hline 1997 Jan. & 75 & $"$ & $"$ & $"$ & $"$ & $"$ & $"$ \\
\hline
\end{tabular}

Continua... 
Tabela 2 - Continuação

\begin{tabular}{|c|c|c|c|c|c|c|c|c|}
\hline 1999 & Mar. & $"$ & 30 & " & $"$ & $"$ & $"$ & $"$ \\
\hline & Maio & " & 25 & " & $"$ & $"$ & $"$ & $"$ \\
\hline & Jul. & $"$ & 20 & " & $"$ & $"$ & $"$ & $"$ \\
\hline & Ago. & $"$ & $"$ & " & $"$ & 0 & 0 & $"$ \\
\hline & Set. & $"$ & 10 & $"$ & $"$ & $"$ & $"$ & $"$ \\
\hline & Out. & 65 & 0 & $"$ & $"$ & $"$ & $"$ & " \\
\hline 2000 & Mar. & 55 & " & " & $"$ & " & $"$ & $"$ \\
\hline & Jun. & 45 & $"$ & $"$ & $"$ & $"$ & $"$ & $"$ \\
\hline 2001 & Set. & $"$ & 10 & " & $"$ & $"$ & $"$ & " \\
\hline 2002 & Jun. & $"$ & 15 & $"$ & $"$ & $"$ & $"$ & " \\
\hline & Jul. & $"$ & $"$ & 20 & $"$ & $"$ & $"$ & " \\
\hline 2003 & Fev. & 60 & $"$ & $"$ & $"$ & $"$ & $"$ & " \\
\hline & Ago. & 45 & $"$ & " & $"$ & $"$ & $"$ & " \\
\hline 2005 & Dez. & $"$ & $"$ & $"$ & $"$ & $"$ & $"$ & $"$ \\
\hline
\end{tabular}

(1) A partir de agosto de 2002 começou a vigorar recolhimento adicional sobre recursos à vista (3\%), depósitos a prazo (3\%) e depósitos de poupança (5\%). A partir de outubro de 2002, as alíquotas dos recolhimentos adicionais sobre os recursos à vista, depósitos a prazo e depósitos de poupança passaram para 8\%, 8\% e 10\%, respectivamente.

(2) No período de junho de 1994 a junho de 1995 as alíquotas de $100 \%$ e de $90 \%$ referem-se ao acréscimo em relação ao período-base apurado entre os dias 23 e 30 de junho de 1994. A partir de julho de 1995 a incidência do compulsório refere-se exclusivamente à média aritmética dos saldos diários de cada período de cálculo.

Fonte: Banco Central do Brasil (2005a). 
Embora extrapole os propósitos deste artigo, faz-se oportuno registrar que as disparidades entre as operações realizadas sob encargos pós-fixados e flutuantes, vis-à-vis as modalidades contratadas sob encargos prefixados, são explicadas pelo fato de as duas primeiras transferirem, respectivamente, os riscos de câmbio e juros ao mutuário. Este constitui o principal fator que explica a razão de o spread prevalecente nas operações prefixadas da modalidade conta garantida ter atingido $44,3 \%$ a.a. na média do período considerado, contra $9,4 \%$ a.a. nas operações flutuantes, uma diferença de 34,9 pontos percentuais (p.p.), conforme se pode observar na Tabela 3. Ou seja, o elevado desvio ocorre em razão de o banco transferir o risco envolvido na operação para o mutuário.

Finalmente, a diferença entre os spreads de um mesmo grupo de tomadores de empréstimos contratados sob os mesmos encargos resulta, sob diferentes graus de importância, de um amplo conjunto de vetores, além da extração de rendas informacionais dos mutuários pelos bancos e do poder de barganha do tomador junto à instituição bancária, conforme já mencionado. A existência de colaterais líquidos e com mercados secundários organizados faz com que, por exemplo, o diferencial cobrado entre as taxas de aplicação e captação de recursos da modalidade aquisição de veículos seja bastante inferior à observada da modalidade crédito pessoal, especificamente no tocante às operações com pessoas físicas contratadas sob encargos prefixados (Tabela 3). Isso significa que, quanto mais assegurada for a modalidade, via aval e fiança, hipoteca e garantia fiduciária e outras, menor tenderá a ser o spread cobrado pelos bancos, visto que sob situações de inadimplência, ${ }^{16}$ essas instituições poderão realizar celeremente os colaterais $^{17}$ (Fachada; Figueiredo; Lundberg, 2003).

A inexistência de produtos bancários substitutos, por seu turno, também afetará as margens cobradas pelos bancos nos empréstimos. Na modalidade cheque especial, por exemplo, o fato de a alternativa para o mutuário que precisa de crédito por apenas alguns dias ser a contratação de recursos com prazo mínimo de um mês, abre um canal de obtenção de lucros extraordinários pelos bancos que ofertam o produto. Isso porque, a despeito de a modalidade incorporar juros diários elevadíssimos, o custo para o mutuário incorrido no prazo de contratação do empréstimo ainda assim será inferior ao incorrido caso se optasse pela modalidade com prazo mínimo de contratação de um mês ${ }^{18}$ (Chu; Nakane, 2005).

(16) Conforme será analisado, a inadimplência representa um importante componente do spread bancário no Brasil.

(17) No entanto, como será discutido na seção 4, sob determinadas circunstâncias os bancos podem sobrevalorizar o papel das garantias no processo de precificação do crédito.

(18) A importância de cada um dos componentes do spread, conforme será discutido a seguir, irá explicar a sua dimensão em cada uma das modalidades existentes, sejam contábeis ou comportamentais, como o risco jurídico, o risco de juros, etc. 
Tabela 3

Estatísticas descritivas sobre spreads bancários no Brasil, por modalidade de crédito (jul. 1994 a dez. 2005)

\begin{tabular}{|c|c|c|c|c|c|c|}
\hline Modalidades de crédito & $\begin{array}{l}\mathrm{N}^{\mathrm{o}} \text { obs. } \\
\text { mensais }\end{array}$ & Mínimo & Máximo & Mediana & Média & $\begin{array}{l}\text { Desv. } \\
\text { padrão }\end{array}$ \\
\hline \multicolumn{7}{|l|}{ Pessoa Física (PF) } \\
\hline \multicolumn{7}{|l|}{ Encargos prefixados } \\
\hline Média Pessoa Física & 138,0 & 42,7 & 184,8 & 60,2 & 80,9 & 40,7 \\
\hline Cheque especial & 72,0 & 123,7 & 153,8 & 133,9 & 135,2 & 8,0 \\
\hline Crédito pessoal & 72,0 & 46,3 & 74,0 & 56,7 & 58,9 & 6,7 \\
\hline Aquisição de veículos & 67,0 & 14,7 & 25,5 & 18,3 & 19,0 & 2,5 \\
\hline Aquisição de outros bens & 67,0 & 34,7 & 65,6 & 46,4 & 47,1 & 6,0 \\
\hline \multicolumn{7}{|l|}{ Pessoa Jurídica (PJ) } \\
\hline Encargos prefixados, pós-fixados e flutuantes & 67,0 & 10,8 & 17,7 & 13,5 & 13,5 & 1,5 \\
\hline \multicolumn{7}{|l|}{ Encargos prefixados } \\
\hline Média Pessoa Jurídica & 138,0 & 19,9 & 106,7 & 28,6 & 40,3 & 24,1 \\
\hline Conta garantida & 96,0 & 26,7 & 57,7 & 44,8 & 44,8 & 8,1 \\
\hline Desconto de notas promissórias & 96,0 & 27,6 & 72,0 & 36,9 & 39,8 & 9,9 \\
\hline Desconto de duplicatas & 96,0 & 21,7 & 65,4 & 30,2 & 34,6 & 11,5 \\
\hline Hot money & 96,0 & 24,2 & 66,7 & 33,9 & 36,0 & 9,3 \\
\hline Capital de giro & 96,0 & 11,2 & 72,9 & 20,2 & 28,6 & 18,4 \\
\hline Aquisição de bens & 96,0 & 8,2 & 34,1 & 13,1 & 15,6 & 6,4 \\
\hline Vendor & 96,0 & 3,1 & 19,4 & 6,0 & 7,4 & 3,7 \\
\hline \multicolumn{7}{|l|}{ Encargos flutuantes } \\
\hline Média Pessoa Jurídica & 67,0 & 7,6 & 10,7 & 9,1 & 9,1 & 0,8 \\
\hline Hot money & 67,0 & 6,0 & 21,2 & 10,7 & 11,3 & 3,2 \\
\hline Capital de giro & 67,0 & 6,3 & 15,5 & 9,5 & 9,5 & 1,8 \\
\hline Conta garantida & 67,0 & 7,2 & 12,3 & 9,3 & 9,3 & 1,2 \\
\hline Aquisição de bens & 67,0 & 3,7 & 10,7 & 7,8 & 7,8 & 1,4 \\
\hline Vendor & 67,0 & 0,5 & 19,1 & 4,6 & 5,3 & 3,0 \\
\hline \multicolumn{7}{|l|}{ Encargos pós-fixados } \\
\hline Média Pessoa Jurídica & 67,0 & 1,3 & 17,5 & 3,6 & 4,5 & 3,5 \\
\hline Repasses externos & 67,0 & 0,8 & 28,2 & 3,7 & 5,3 & 5,7 \\
\hline Adiantamento de Contrato de Câmbio (ACC) & 67,0 & 1,6 & 8,9 & 3,5 & 3,8 & 1,6 \\
\hline \multicolumn{7}{|l|}{ Média geral (PF e PJ) } \\
\hline Encargos prefixados & 138,0 & 34,5 & 146,4 & 46,5 & 60,0 & 31,6 \\
\hline Encargos prefixados, pós-fixados e flutuantes & 67,0 & 25,3 & 33,7 & 29,0 & 29,0 & 2,1 \\
\hline
\end{tabular}

Nota: Apenas os spreads médios cobrados de pessoas físicas e jurídicas nas operações prefixadas têm a série iniciada em julho de 1994, apresentando um número de observações (n) de 138. As demais modalidades contêm um número de observações menor em razão de o início da série se dar apenas em janeiro de 1998 (n. observações $=96$ ), janeiro de 2000 (n. observações $=72$ ) e junho de 2000 (n. observações $=67$ ). Os dados de mínimo, máximo, mediana e média são expressos em $\%$ ao ano.

Fonte: Banco Central do Brasil (5 fev. 2006).

No intuito de ratificar a necessidade de redução do spread bancário no país, a Figura 3 apresenta a relação entre o volume de crédito livre, ${ }^{19}$ expresso a

(19) São os aprimoramentos realizados a partir da Circular 2.957, de 30 de dezembro de 1999, do Banco Central do Brasil, que explicam o aumento de $\mathrm{R} \$ 30,8$ bilhões (preços constantes) observado no volume das operações de crédito com recursos livres, entre abril e maio de 2000, significando, de certa forma, uma "quebra" na série histórica. A partir de 31 de maio de 2000 foram incorporadas: a) novas modalidades de crédito informadas, inclusive e principalmente "outras operações", antes não informadas ao Banco Central; b) mais instituições informantes; e c) em alguns casos e, portanto, em menor medida, operações pactuadas sob os demais tipos de encargos, além dos prefixados. Nesse sentido, os valores de volume (estoque) de crédito captaram tais 
preços constantes de julho de 2005, e a margem média cobrada pelos bancos nas operações prefixadas no Brasil. $^{20}$

Figura 3

Relação entre crédito livre e spread bancário no Brasil (out. 1996 a dez. 2005)

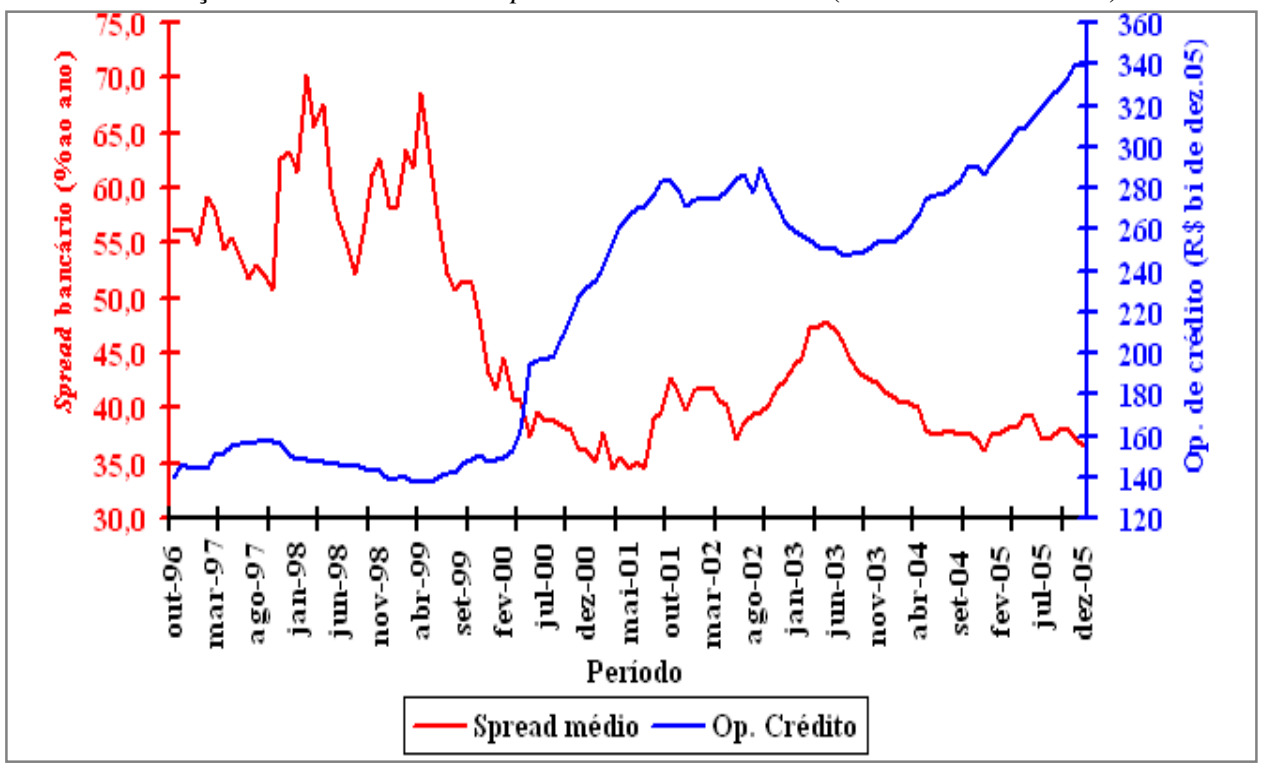

Nota: Deflator: IPCA. Valores das operações de crédito a preços constantes de dez. 05.

Fonte: Adaptado de Banco Central do Brasil (05 fev. 2006).

Verifica-se claramente a existência de um alto grau de correlação (inversa) entre as variáveis, indicando que a prática de elevados spreads reprime o aumento das operações de empréstimos, pois torna o preço do dinheiro muito elevado e, ao cabo, reduz a demanda por crédito. Portanto, uma alta diferença entre as taxas de aplicação e captação de recursos afeta desfavoravelmente o adensamento das relações de crédito e débito da economia, atravancando o ciclo de negócios e

mudanças já em maio de 2000. Já a divulgação dos valores de fluxo viria a ter início apenas no mês seguinte (junho de 2000).

(20) Os dados sobre crédito se referem ao total do saldo (estoque) consolidado no mês das operações de crédito com recursos livres, englobando todos os tipos de encargos pactuados (pré e pós-fixados, flutuantes e índice de preços). Já os dados sobre spread bancário referem-se à média das margens cobradas pelos bancos em suas operações de créditos livres pactuadas sob encargos prefixados. Em primeiro lugar, cumpre salientar que o ideal seria cruzar os spreads prefixados com o fluxo das operações de crédito pactuadas sob encargos prefixados. Todavia, os dados sobre fluxo são disponibilizados apenas a partir de junho de 2000, impedindo uma observação mais ampla da relação inversa apresentada. Posta essa limitação, o melhor seria apresentar os valores de crédito de estoque apenas das operações prefixadas. Todavia, tais dados são disponíveis sob a forma agregada apenas a partir de maio de 2000, o que implicaria novamente uma série muito curta. Levando em conta essas restrições e considerando que as operações de crédito pactuadas sob encargos prefixados representam a maior parte do crédito com recursos livres no país, tanto em termos de estoque quanto de fluxo, pode-se afirmar que a relação inversa apresentada entre crédito e spread bancário é pertinente. 
obstaculizando o processo de retomada do crescimento econômico sustentado, condições que tornam premente a correção dessa distorção.

\section{Decomposição contábil do spread bancário no Brasil}

A decomposição contábil do spread bancário no Brasil elaborada pelo Banco Central do Brasil (BCB), antes baseada nas margens cobradas por uma amostra de dezessete grandes bancos privados em suas operações de crédito livres contratadas sob taxas de juros prefixadas, ${ }^{21}$ a partir do relatório de cinco anos de avaliação do Projeto Juros e Spread Bancário passou a ser calculada nos números contábeis de mais de $80 \%$ das instituições financeiras operantes no país, ${ }^{22}$ além de contemplar mais um componente (depósito compulsório) em relação à metodologia anterior (Banco Central do Brasil, 2004).

Em vez de realizar uma análise comparativa entre ambas as metodologias de cálculo da composição contábil do spread bancário no Brasil, ${ }^{23}$ o que importa destacar é que na mais recente decomposição, apresentada em BCB (2005), são considerados os seguintes fatores: a) custo FGC; b) despesa com inadimplência; c) custo total do compulsório; d) custo administrativo; e) cunha tributária; f) inadimplência; e g) resíduo ou lucro do banco, que inclui outros fatores não considerados na decomposição, e que, por essa razão, é também chamado de "resíduo". A Tabela 4 apresenta a participação de cada um desses componentes no spread bancário no período 2001-2004.

Na mais recente metodologia de cálculo da composição contábil do spread bancário, abandona-se o pressuposto até então utilizado de existência de independência entre os mercados de captação e empréstimo, passando-se a fazer uso do pressuposto da dependência entre esses mercados. ${ }^{24}$ É por essa perspectiva

(21) Foram consideradas dez modalidades de crédito, operações realizadas com recursos livres e contratadas sob juros prefixados, a saber: a) pessoas físicas - cheque especial, crédito pessoal e aquisição de bens; b) pessoas jurídicas - hot money, conta garantida, desconto de duplicatas, desconto de notas promissórias, capital de giro, aquisição de bens e vendor.

(22) Em 2001, foram considerados 100 bancos; em 2002, 73 bancos; em 2003, 83 bancos; e em 2004, última posição disponível, 86 bancos.

(23) Sobre a nova metodologia de cálculo, ver Costa e Nakane (2004). A nova metodologia, além de ter ampliado a amostra para a apuração dos determinantes do spread bancário sob uma abordagem puramente contábil, introduziu o novo componente "depósito compulsório" e passou a fazer uso de uma nova metodologia de cálculo para a mensuração do componente "custo administrativo", antes baseada na hipótese de que os bancos alocam seus recursos administrativos proporcionalmente ao retorno de cada uma das modalidades de crédito consideradas na mensuração dos componentes, e agora baseada na teoria de alocação de custos conjuntos, método que leva em conta a noção de custo da unidade de concessão de empréstimos livres (Costa; Nakane, 2004).

(24) Embora esse pressuposto possa indicar a necessidade de captação de recursos para a concessão de crédito, fenômeno inverossímil à luz do referencial teórico pós-keynesiano, mostra-se admissível supor que a imposição de restrições à política de captação dos bancos, a despeito de não impedir a concessão de recursos, acaba implicando custos adicionais para essas instituições, haja vista que os recursos indisponibilizados poderiam estar potencializando a política de valorização da riqueza levada a cabo por essas instituições. 
que deve ser feita a leitura do componente depósito compulsório do spread bancário no Brasil, que no período 2001-2004 representou em média 8,79\% das margens bancárias aplicadas nas operações de empréstimos, e que chegou a ultrapassar $12 \%$ em 2002, por conta da imposição de exigibilidades adicionais de recolhimentos no período, iniciativa minimizada pela redução da taxa básica de juros a partir de 2003 (Banco Central do Brasil, 2004; 2005b).

Tabela 4

Composição do Spread bancário no Brasil, em \% (2001-2004)

\begin{tabular}{l|r|r|r|r|r}
\hline Componentes do spread & 2001 & 2002 & 2003 & 2004 & Média \\
\hline 1. Spread total & 100,00 & 100,00 & 100,00 & 100,00 & 100,00 \\
\hline 2. Custo administrativo & 19,84 & 16,54 & 21,87 & 21,86 & 20,03 \\
\hline 3. Inadimplência & 31,04 & 31,25 & 31,73 & 33,97 & 32,00 \\
\hline 4. Custo do compulsório & 9,51 & 12,13 & 6,51 & 7,00 & 8,79 \\
\hline 4.1 Depósitos à vista & 9,23 & 9,94 & 7,09 & 6,85 & 8,28 \\
\hline 4.2 Depósitos a prazo & 0,28 & 2,20 & $-0,57$ & 0,15 & 0,52 \\
\hline 5. Tributos e taxas & 7,10 & 7,26 & 7,24 & 8,37 & 7,49 \\
\hline 5.1 Impostos indiretos & 6,82 & 6,98 & 6,98 & 8,11 & 7,22 \\
\hline 5.2 Custo do FGC & 0,28 & 0,28 & 0,26 & 0,26 & 0,27 \\
\hline 6. Resíduo bruto (1-2-3-4-5) & 32,51 & 32,82 & 32,65 & 29,10 & 31,77 \\
\hline 7. Impostos diretos & 11,14 & 10,41 & 9,88 & 9,30 & 10,18 \\
\hline 8. Tributação total (5.1+7) & 17,96 & 17,39 & 16,86 & 17,41 & 17,41 \\
\hline 9. Resíduo líquido (6-7) & 21,37 & 22,40 & 22,77 & 19,80 & 21,59 \\
\hline Fon Banco Centra
\end{tabular}

Fonte: Banco Central do Brasil (2005b, p.10).

As despesas com inadimplência, que pela decomposição realizada pelo Banco Central correspondem a $20 \%$ das provisões mínimas realizadas pelos bancos em suas operações de empréstimos, de acordo com a Resolução 2.682/1999, representam parcela significativa do spread bancário no Brasil, 32\% na média do intervalo 2001-2004. No interregno 2001-2003, o componente referente à inadimplência apresentou comportamento estável, em torno de $31 \%$ do spread cobrado pelos bancos em suas operações de crédito com recursos livres. Pode-se atribuir a elevada participação desse componente mormente ao ambiente macroeconômico altamente instável, às deficiências institucionais que atuam no sentido de estimular comportamentos oportunísticos por parte dos tomadores de crédito, bem como às próprias altas taxas de juros prevalecentes nas operações de empréstimos, vetor que se configura como grande responsável pela incapacidade de parcela dos mutuários honrarem as suas dívidas. Em 2004, observou-se uma participação ainda maior desse componente, refletindo o processo de recuperação do crédito no país e o conseqüente aumento do provisionamento realizado pelos bancos (Tabela 4).

As despesas administrativas dos bancos, antes apuradas a partir do custo médio administrativo incorrido na unidade de negócio "concessão de crédito 
livre", ${ }^{25}$ assumindo-se a hipótese de que essas instituições alocavam seus recursos administrativos proporcionalmente aos retornos que as respectivas modalidades de empréstimos geravam, a partir de 2004 passam a ser quantificadas tomando-se por base a teoria da alocação de custos conjuntos, e não a de geração de receitas. Nessa perspectiva, os depósitos são concebidos como insumos, e não como produtos oferecidos pelos bancos, condição que aproxima o modus operandi dessas instituições ao das empresas não financeiras. No entanto, embora supere os propósitos deste artigo, cumpre salientar esse pressuposto não se sustenta à luz do referencial teórico pós-keynesiano, segundo o qual os bancos são entendidos como instituições ativas capazes de criar moeda, cujos depósitos que darão suporte à operação poderão ser obtidos a posteriori. Essa incompatibilidade indica a necessidade de se realizar uma decomposição do spread bancário a partir de axiomas mais compatíveis com o referencial pós-keynesiano.

Os custos administrativos, sob a nova metodologia de cálculo, ${ }^{26}$ respondem por $20,03 \%$ do spread, na média do período considerado (Tabela 4). Por corresponder a uma parcela significativa das margens cobradas pelos bancos em suas operações de empréstimos, pode-se inferir que não obstante a queda substancial desses custos em relação aos níveis observados logo após o Plano Real, reflexo do processo de redimensionamento do setor ocorrido após a queda da alta inflação, ${ }^{27} \mathrm{o}$ alto número de agências bancárias ainda existente e a baixa alavancagem das operações de empréstimos no país tornam as despesas administrativas dos bancos no Brasil bem mais elevadas que o verificado no sistema bancário de países desenvolvidos. O aumento da escala das operações tenderia a reduzir o peso dessas despesas, pela diluição dos custos fixos (Banco Central do Brasil, 2001).

Os seguintes impostos são considerados para o cálculo do componente da tributação: Programa de Integração Social (PIS), Contribuição para o Financiamento da Seguridade Social (COFINS), Contribuição Social sobre o Lucro Líquido (CSLL), Imposto de Renda (IR) e Imposto sobre Operações Financeiras (IOF). ${ }^{28}$ Portanto, além da tributação indireta, o Banco Central

(25) Este custo é obtido pelo desmembramento do percentual obtido pela razão entre as receitas com operações de crédito livres e as receitas totais dos bancos no total das despesas administrativas incorridas em cada uma das operações de crédito. As unidades de empréstimos consideradas foram: concessão de crédito livre, concessão de outros créditos, câmbio, títulos e valores mobiliários, arrendamento mercantil e serviços.

(26) Os custos administrativos são estimados a partir de uma função custo que desconsidera as receitas de serviços e os custos administrativos não são divididos proporcionalmente à receita bruta gerada pelas operações de crédito (Banco Central do Brasil, 2005; 2006).

(27) Sobre o processo de reestruturação do sistema bancário ocorrido após o Plano Real, ver IBGE (1997) e Barros; Loyola; Bogdanski (1998).

(28) A COFINS, o PIS e o IOF incidem sobre todas as movimentações financeiras e oneram a captação de recursos pelos bancos. Já a CSLL é um adicional do IR, um imposto direto sobre o lucro dos bancos, seja ele gerado pelas operações de crédito ou não. 
considera a tributação direta. Todavia, a inclusão do IR e da CSLL pode ser questionada, vez que ao contrário dos tributos indiretos, que oneram cada operação financeira e não são restituíveis, os tributos diretos incidem sobre os rendimentos de todas as operações dos bancos e dos depositantes e não são específicos da atividade financeira. ${ }^{29}$ Tal discussão, no entanto, extrapola o escopo de análise deste artigo.

Na média do interregno analisado, a tributação representou $17,41 \%$ da margem cobrada pelos bancos em suas operações de empréstimos com recursos livres pactuadas sob taxas de juros prefixadas, da qual 10,18 p.p. corresponderam aos impostos diretos e 7,22 p.p. aos impostos indiretos. Já o Fundo Garantidor de Créditos (FGC), ${ }^{30}$ representou em média 0,27\% das margens bancárias (Tabela 4).

Finalmente, considerando a média do período, a margem apropriada pelos bancos nos empréstimos dos bancos apurada por resíduo, após a incidência de tributação direta, representou o segundo componente mais importante do spread cobrado por essas instituições, 21,59\%, perdendo apenas para as despesas com inadimplência, que pela metodologia utilizada pelo Banco Central correspondem a $20 \%$ do provisionamento dos bancos. No mais, cumpre registrar que embora próximo, o resíduo não deve ser considerado sinônimo de lucro do banco, seja por incorporar eventuais erros de medida ${ }^{31}$ dos demais componentes identificados, seja por contemplar componentes não considerados na decomposição contábil, que embora não impliquem despesas monetárias efetivamente incorridas, podem afetar as margens cobradas por essas instituições em seus empréstimos (Nakane, 2003).

\section{0 componente "custo de oportunidade" do spread bancário no Brasil}

A análise do comportamento do spread bancário no Brasil no período 1994-2005 revelou que, a despeito dos esforços realizados pelo Banco Central para o entendimento dos condicionantes das margens cobradas pelos bancos em suas operações de empréstimos e das iniciativas adotadas para minimizar seus efeitos, os diferenciais cobrados por essas instituições entre as suas taxas de captação e aplicação de recursos permanecerem muito elevados. Isso, aliado ao fato de os spreads terem caído timidamente após a implementação do projeto, quando da comparação em relação ao período anterior (Figura 1), sugere a

(29) No mais, cumpre salientar que o impacto dos impostos diretos (IR e CSLL) no spread dependeu da estimação das despesas com inadimplência e administrativas, vez que estas alteram a base de cálculo dos tributos (Banco Central do Brasil, 2001).

(30) A cunha proveniente do FGC é composta pela necessidade de captação devido à retenção no Fundo e pelo custo destes recursos para os bancos. Para maiores detalhes, ver Banco Central do Brasil (2001).

(31) Em relação aos possíveis erros de medida capturados pela margem líquida do banco, Nakane (2003) menciona o componente relativo à inadimplência calculado pelo Banco Central, o qual, segundo o autor, deveria incorporar não somente o fluxo de despesa com inadimplência incorrida pelo banco, mas também o processo de recuperação de garantias e do valor concedido pela instituição financeira. 
existência de condicionantes de ordens mais estruturais que explicam as altas margens cobradas pelos bancos no país.

Além dos condicionantes apurados a partir da decomposição contábil do spread bancário, as margens cobradas pelos bancos nas operações de crédito são também influenciadas por fatores comportamentais, de ordens microeconômicas, macroeconômicas e institucionais. De acordo com Fuentes e Basch (2000, p. 117):

Hypothetically, three kinds of factors can influence spreads: microeconomic (the management of commercial banks, risk management, and market functioning), macroeconomic (monetary policy and inflation, exchange policy, and the exchange rate) and institutional (bank legislation and supervision).

É com base nisso que Pinheiro (2003) chama atenção ao que denominou de "componente judicial" do spread bancário, o qual se relaciona aos impactos negativos acarretados por um sistema judicial ineficiente sobre as margens cobradas pelos bancos em seus empréstimos. Também é nessa perspectiva que Afanasieff; Lhacer e Nakane (2002) concluíram que fatores macroeconômicos são mais importantes que os microeconômicos para explicar o comportamento do spread bancário no Brasil, com destaque à taxa básica de juros. Na mesma direção, Ono; Silva; Oreiro e Paula (2005) destacam a importância do ambiente macroeconômico para a explicação das altas margens bancárias praticadas pelos bancos no país em seus empréstimos, destacando que o elevado risco de juros envolvido nas operações de crédito acaba implicando maior spread.

Nessa perspectiva, pode-se considerar que um outro fator de grande relevância para explicar o alto spread bancário no país, mas que tem recebido destaque apenas parcial nas análises do problema, ${ }^{32}$ diz respeito ao nível da taxa básica de juros da economia. Essa parcialidade decorre do fato de a maior parte dos estudos que fazem referência à taxa Selic como variável explicativa das elevadas margens cobradas pelos bancos em seus empréstimos levar em consideração apenas os seus impactos sobre o componente inadimplência. ${ }^{33}$

No entanto, a prática de elevada taxa de juros básica da economia faz aumentar o spread bancário não somente por elevar o risco de inadimplência envolvido nas operações de crédito, já que o aumento do custo de captação implica maior taxa de juros final e, ao cabo, problematiza a capacidade de pagamento do mutuário, mas também por implicar um alto custo de oportunidade envolvido na concessão de empréstimos, custo este representado pela taxa própria de juros dos títulos públicos federais. Esses ativos permitem aos bancos a consolidação de uma

(32) Exceções são os recentes trabalhos de Oliveira e Carvalho (2003), Paula (2003) e Paula e Alves Jr. (2003).

(33) O aumento da taxa básica de juros, ao implicar maior custo de captação para os bancos e afetar negativamente as expectativas dos agentes, faz aumentar o risco de crédito envolvido nas operações de empréstimos. 
estrutura operacional que coaduna atrativos retornos monetários e não monetários, minimizando o trade-off retorno versus liquidez e aumentando o prêmio de risco cobrado por essas instituições em suas operações de crédito (Oliveira; Carvalho, 2003).

Como se sabe, a taxa de juros básica praticada no Brasil está há anos entre as maiores do mundo. ${ }^{34}$ Ranking elaborado periodicamente pela consultoria GRC Visão (2005) mostra que nos últimos anos o Brasil se afigurou permanentemente como o país com a maior taxa real de juros ex ante ${ }^{35}$ entre os 40 países selecionados na amostra. Em vez de se tratar de uma condição esporádica, desde o Plano Real a taxa básica real de juros sempre esteve entre as maiores taxas de juros do planeta.

Pelo fato de a Selic representar o retorno médio dos títulos públicos, esses ativos passam a ser muito atrativos para os bancos, vez que oferecem altos retornos monetários $(\boldsymbol{q}-\boldsymbol{c})$, elevada liquidez $(\boldsymbol{l})$ e, de um modo geral, baixa variação de seus valores de mercado $(\boldsymbol{a})$. Isso significa que os altos juros praticados pelo governo brasileiro permitem que a preferência por liquidez dos bancos não implique abstenção pela preferência por rentabilidade, dados os referidos atributos dos títulos públicos. De modo que as operações de crédito passam a ter um custo de oportunidade considerável, representado pela remuneração daqueles ativos. Além de se configurar uma aplicação cuja rentabilidade se mostra atrativa, a alocação de recursos em títulos públicos, afirma Paula (2003, p. 3):

[...] permite aos bancos - quando lhes convém - fazer um hedge (seguro) contra a desvalorização cambial e a elevação da taxa de juros. Aplicações em títulos públicos representam um piso para o rendimento dos bancos, o que aumenta sobremaneira o custo de oportunidade para concessão de empréstimos por parte dos bancos, que passam a cobrar um prêmio de risco elevadíssimo nas operações de empréstimo.

Isso significa que a taxa própria de juros dos títulos públicos irá representar a base de cálculo para todas as demais operações ativas dos bancos disponíveis no mercado, já que essas instituições não incorporam no spread cobrado na concessão de empréstimos o custo de oportunidade de se manter recursos em caixa, mas a rentabilidade sacrificada por deixar de aplicar os recursos destinados às operações de crédito em títulos públicos federais.

A Figura 4 apresenta a relação existente entre taxa básica da economia e o spread praticado pelos bancos no Brasil (ago. 1994 a dez. 2005). Pode-se observar

(34) Para os objetivos deste artigo, pois, o relevante é destacar que a prática de alta taxa básica de juros exerce impacto importante sobre o diferencial cobrado pelos bancos entre as suas taxas de captação e aplicação de recursos.

(35) Taxa de juros nominal descontada a inflação projetada para os próximos 12 meses. 
o elevado grau de correlação entre os juros básicos da economia e o spread bancário. Taxa de juros básica maior está associada a um maior diferencial cobrado pelos bancos em seus empréstimos. Conforme já destacado, isso ocorre não apenas pelo maior risco de inadimplência envolvido nas operações de crédito, mas também pelos altos retornos monetários e não monetários oferecidos pelos títulos públicos, considerados pelos bancos quando da estipulação do diferencial cobrado entre as suas taxas de captação e aplicação de recursos (Oliveira; Carvalho, 2003).

Figura 4

Relação entre taxa básica de juros e spread bancário no Brasil (ago. 1994 a dez. 2005)

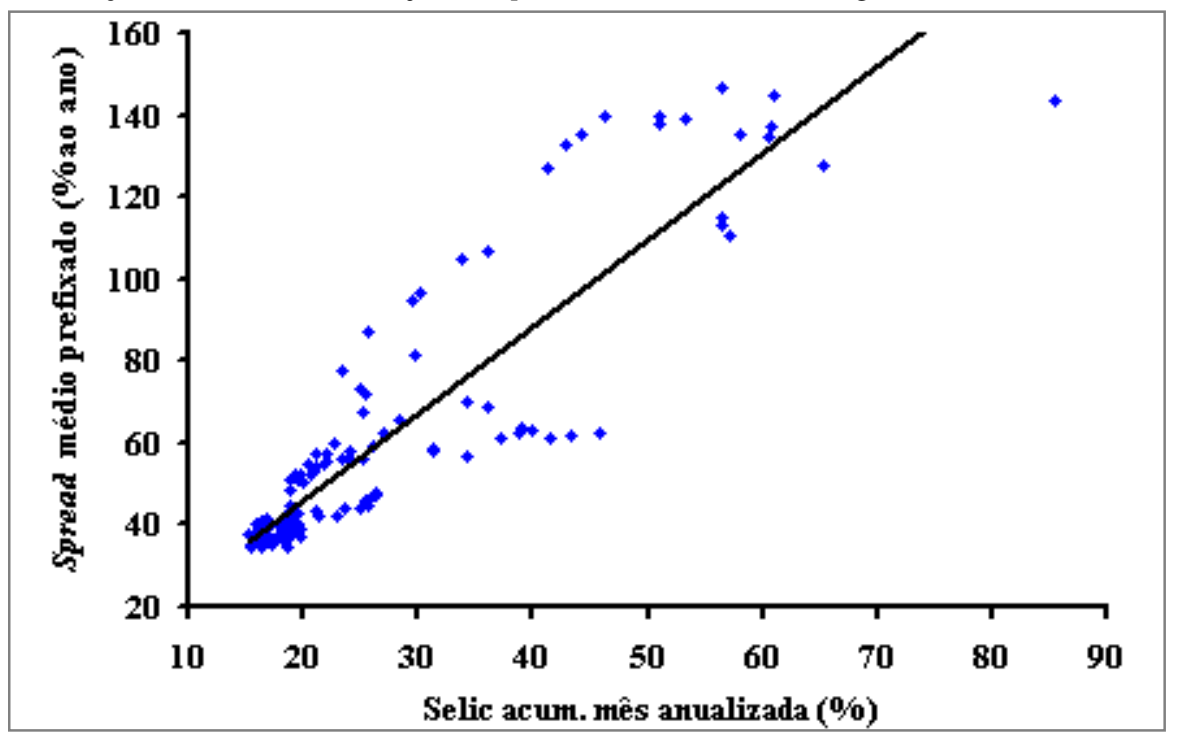

Fonte: Adaptado de Banco Central do Brasil (05 fev. 2006).

O maior "prêmio de risco" embutido nas operações de crédito se traduz não apenas em maior spread bancário e racionamento de crédito, mas também em maior exigência de colaterais quando da realização de empréstimos por parte dos bancos, conduta que reflete a maior aversão ao risco por parte dessas instituições. Uma vez que os bancos podem optar pela aplicação em papéis líquidos, seguros e rentáveis, o grau de aversão ao risco dessas instituições se torna muito elevado. Importante destacar, ainda, que tais atributos permitem a consolidação de um portfólio que, além de propiciar a obtenção de ganhos significativos, mostra-se altamente responsivo às novas oportunidades percebidas de lucro, em face da elevada liquidez dos títulos públicos federais. É nesse contexto que Carvalho 
(2005, p. 339), em um dos poucos estudos ${ }^{36}$ que relevam a papel da taxa de juros como custo de oportunidade das operações de crédito, providencialmente afirma que:

A ampla disponibilidade de títulos públicos é capaz de satisfazer a busca de lucros por parte dos bancos. Ofertar crédito é uma atividade apenas complementar, e só é atraente à medida que possa oferecer ganhos muito altos, para compensar o custo de oportunidade, tanto em rentabilidade quanto em segurança, da aplicação em papéis públicos. [grifo nosso]

Faz-se importante registrar, ainda, que o grau de importância do componente custo de oportunidade do spread bancário irá depender de um conjunto de fatores que atua sobre o processo de formação de expectativas dos bancos, como o grau de exposição do lado esquerdo do balanço em determinadas operações ativas; as expectativas dessas instituições quanto ao comportamento futuro da economia; a condução da política monetária; e a demanda por crédito pelo público. Decorre, nessa perspectiva, que sob contextos de instabilidade macroeconômica, o componente custo de oportunidade tende a possuir maior importância do que sob ambientes de maior estabilidade.

Logo, o papel da garantia tende a ser sobrevalorizado pelos bancos quando da concessão de empréstimos, pois irão optar por conceder crédito basicamente quando o risco envolvido nessas operações: a) for praticamente nulo, como por exemplo os empréstimos para as grandes empresas e com desconto em folha de pagamento para pessoas físicas; b) for compensado pelos bons pagadores; e c) for coberto por colaterais líquidos e de fácil execução, como a concessão de crédito para aquisição de veículos. De acordo com Andima (2001, p. 73):

A liquidez assume papel preponderante para as instituições financeiras, diante da volatilidade característica dos mercados em que atuam. O desafio dos bancos brasileiros tem sido o de equilibrar as aplicações em ativos que apresentam alta liquidez e garantia de boa rentabilidade. Geralmente, uma maior alavancagem em títulos públicos geraria receitas menores do que as operações de crédito. Porém, o grau de desenvolvimento do mercado secundário de papéis públicos garante uma liquidez praticamente inexistente no mercado de crédito. Diante dessas duas opções, o setor bancário brasileiro [...] tem optado, ao sabor das instabilidades nos mercados financeiros interno e externo, por manter-se mais alavancado em títulos.

A Figura 5 apresenta a proporção das aplicações em títulos e valores mobiliários (TVM) e das operações de crédito em relação ao total do ativo dos 50

(36) Além do trabalho de Carvalho (2005), deve ser dado destaque aos trabalhos de Oliveira (2004), Oliveira e Carvalho (2003), Andima (2001), Paula e Alves Jr. (2003), além do trabalho também mais recente de Ono; Silva; Oreiro e Paula (2005). 
maiores bancos no Brasil $^{37}$ na posição de cada mês respectivo, no período jun. 2000 a dez. 2005. Pode-se verificar que a participação das aplicações em TVM é praticamente equivalente à parcela do ativo dos bancos direcionada às operações de empréstimos, incluindo as operações em arrendamento mercantil. Juntas, as operações de crédito com as aplicações em TVM representam aproximadamente $60 \%$ do ativo dos 50 maiores bancos do país no interregno considerado, com a ressalva de que a partir de dezembro de 2002 as aplicações em TVM são somadas com as aplicações em instrumentos financeiros derivativos e que em alguns meses a representatividade de tais operações superou a dos empréstimos.

Figura 5

Participação das operações de crédito e das aplicações em TVM no ativo dos 50 maiores bancos no Brasil (jun. 2000 a dez. 2005)

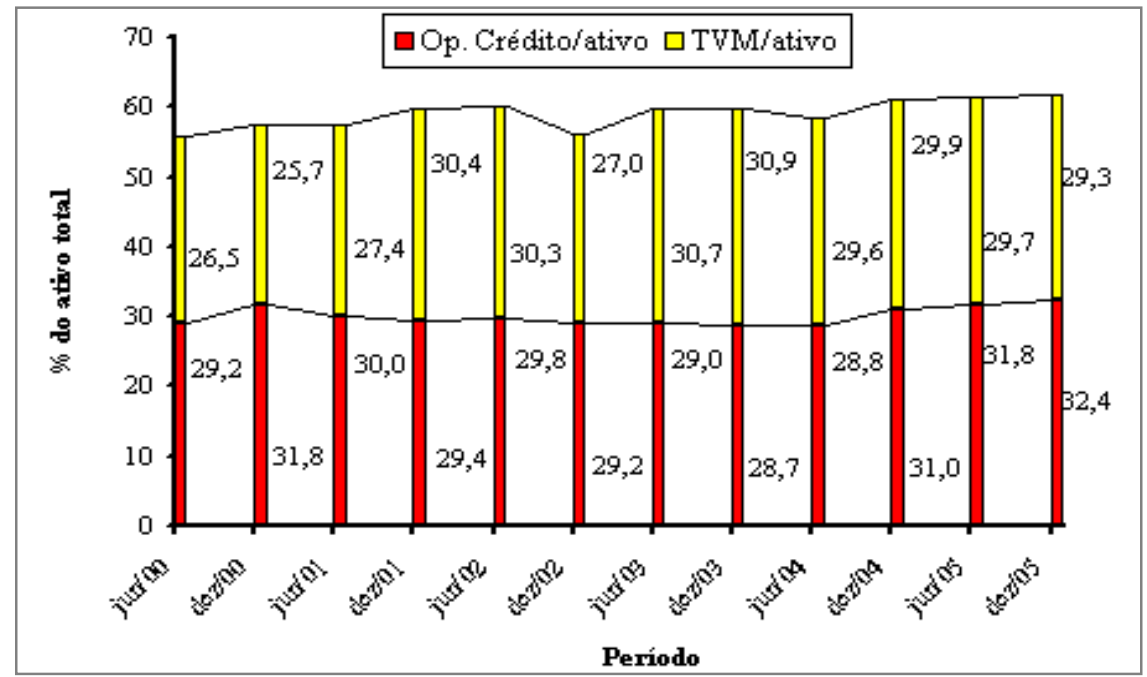

Fonte: Adaptado de Banco Central do Brasil (10 abr. 2006).

Estudo recente realizado pelo Banco Interamericano de Desenvolvimento (BID) mostra que a participação da dívida pública nos ativos totais dos bancos no Brasil é bem superior à observada tanto nos países de alta renda, quanto na maior parte dos países da América Latina. Considerado o período 2000-2001, o relatório mostra que enquanto essa relação alcança pouco mais de $10 \%$ nos países de alta renda e cerca de 15\% na América Latina e Caribe, no Brasil atinge 33\% (BID, 2005, p. 16-17).

(37) Em junho de 2005, a participação do ativo dos 50 maiores bancos do país no total do ativo do Sistema Financeiro Nacional (SFN) era de 83,6\%. Trata-se, portanto, de uma parcela altamente significativa do SFN. 
Não fossem tais operações atrativas, por qual motivo essas instituições destinariam uma proporção tão considerável do ativo para a compra de títulos da dívida pública? Obviamente que uma parte desse perfil de portfólio dos bancos no Brasil se deve às mudanças ocorridas na forma de captação de recursos, com o aumento da importância da captação a partir de instrumentos do mercado monetário, como os fundos de investimento. Não obstante, essa condição de maneira alguma deve ser extrapolada, já que os elevados níveis de rentabilidade apresentados pelo setor bancário no período posterior ao Plano Real evidenciam que o retorno obtido a partir da aquisição de títulos públicos federais vem contribuindo sobremaneira para os bons resultados alcançados. ${ }^{38}$

A Figura 6 mostra a representatividade, expressa em percentagem, das receitas com operações de crédito e com TVM no total das receitas com intermediação financeira dos 50 maiores bancos do país no período respectivo. ${ }^{39}$ Observa-se, que embora as receitas obtidas pelos bancos com os empréstimos sejam maiores do que as adquiridas com operações de TVM em todo o período considerado, fica evidente a importância das últimas na composição das receitas dos bancos. Na posição de junho de 2003, por exemplo, as receitas obtidas com TVM mais instrumentos derivativos representaram $41,1 \%$ da receita total com intermediação financeira, patamar bastante próximo aos $50 \%$ verificados nas operações de crédito mais arrendamento mercantil.

Essa política operacional adotada pelos bancos no Brasil tem proporcionado a essas instituições altas taxas de retorno sobre o patrimônio. A Tabela 5 apresenta o indicador para países desenvolvidos e latino-americanos selecionados. Pode-se observar claramente que os bancos no Brasil estão entre os mais rentáveis da amostra, situando-se no topo da pirâmide dos países cujos sistemas bancários foram mais rentáveis no período 2000-2005. Em 2002 e 2003, por exemplo, o sistema bancário brasileiro apresentou o maior retorno sobre o patrimônio na comparação com os demais. Além disso, e não menos importante, cabe destacar que enquanto nos países desenvolvidos as elevadas taxas de rentabilidade são conquistadas a partir de uma elevada exposição em crédito, no Brasil os bancos obtêm altos retornos a partir de uma estrutura patrimonial diferenciada, com elevada participação das operações com Títulos e Valores Mobiliários e reduzida participação dos empréstimos (BID, 2005).

(38) Ver Paula; Alves Jr. e Marques (2001).

(39) Cumpre registrar que a partir de junho de 2002 as receitas com TVM passam a incorporar as obtidas com instrumentos derivativos financeiros. No mais, durante todo o período, as receitas com operações de crédito contemplam as adquiridas com as operações de arrendamento mercantil. 
Figura 6

Participação das receitas das operações de crédito e das aplicações em TVM na receita de intermediação financeira dos 50 maiores bancos no Brasil (jun. 2000 a dez. 2005)

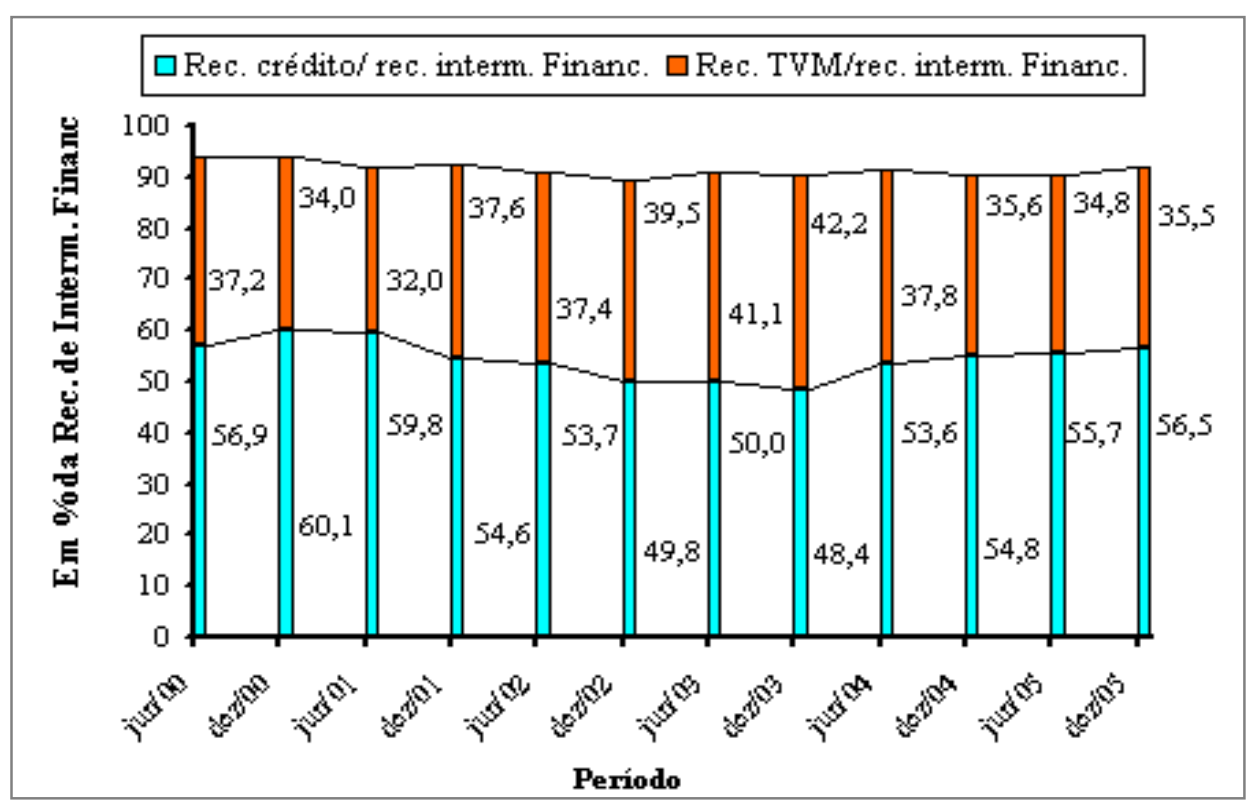

Fonte: Adaptado de Banco Central do Brasil (10 abr. 2006).

Isso mostra que, na realidade, não obstante a transição de um ambiente de alta para baixa inflação ter implicado mudanças importantes no setor bancário brasileiro, notadamente no que diz respeito ao redimensionamento do setor, essa mudança pouco influenciou o comportamento dessas instituições. Tanto na alta quanto na baixa inflação, o modus operandi dos bancos se mostrou fundamentalmente orientado para os ganhos resultantes do financiamento da dívida pública. A transição da alta para a baixa inflação implicou a mudança da forma dos ganhos dos bancos, mas preservou o mecanismo estrutural que permite a obtenção de altos lucros a partir de uma postura operacional líquida. Nesse sentido, afirma Carvalho (2005, p. 236):

Antes da estabilização de preços, a instabilidade inflacionária permitia ao setor bancário obter seus lucros da operação com títulos da dívida pública. Depois da estabilização de preços, a instabilidade do balanço de pagamentos permitiu ao setor bancário continuar obtendo seus lucros da mesma forma.

[...] Quando a percepção dominante foi que a dívida pública deixaria de ser o sustentáculo dos lucros bancários [início do Plano Real], as instituições voltaramse, com grande agilidade, para a ocupação do mercado de crédito privado. Quando, logo em seguida, o governo mostrou-se incapaz de resolver o novo dilema macroeconômico em que se enredara, tornando o apelo à emissão de dívida pública novamente inevitável, o setor bancário simplesmente recompôs sua já conhecida estratégia de atuação. 
Tabela 5

Taxa de retorno sobre o patrimônio do setor bancário em países desenvolvidos e latino-americanos selecionados, em \% (2000 a 2005)

\begin{tabular}{l|r|r|r|r|r|r}
\hline Países selecionados & 2000 & 2001 & 2002 & 2003 & 2004 & 2005 \\
\hline Países desenvolvidos (G7) & & & & & & \\
\hline Alemanha & 6,1 & 4,6 & 2,9 & $-1,5$ & 1,9 & 3,5 \\
\hline Canadá & 15,3 & 13,9 & 9,3 & 14,7 & 16,7 & 14,9 \\
\hline Estados Unidos & 13,5 & 13,0 & 14,1 & 15,0 & 13,2 & 12,7 \\
\hline França & 9,7 & 9,6 & 9,1 & 8,5 & 10,6 & 11,9 \\
\hline Itália & 11,2 & 9,1 & 6,4 & 6,7 & 10,7 & 13,3 \\
\hline Japão & $-0,5$ & $-12,7$ & $-17,9$ & $-2,9$ & 4,3 & 12,6 \\
\hline Reino Unido & 13,5 & 7,7 & 6,1 & 8,6 & 10,9 & 11,8 \\
\hline América Latina & & & & & & \\
\hline Argentina & 3,1 & $-0,2$ & $-59,2$ & $-22,7$ & $-4,2$ & 7,1 \\
\hline Bolívia & $-9,5$ & $-4,1$ & 0,6 & 2,7 & $-1,2$ & 4,2 \\
\hline Brasil & 11,3 & $-1,2$ & 21,8 & 17,0 & 18,8 & 22,8 \\
\hline Chile & 12,7 & 17,7 & 14,4 & 16,7 & 16,7 & 17,9 \\
\hline Colômbia & $-20,7$ & 1,1 & 9,6 & 16,9 & 23,2 & 22,5 \\
\hline México & 10,4 & 8,6 & $-10,4$ & 14,2 & 13,0 & 19,5 \\
\hline Paraguai & 12,4 & 24,1 & 14,3 & 7,7 & 19,4 & 24,3 \\
\hline Peru & 3,1 & 4,3 & 8,3 & 10,7 & 11,6 & 22,2 \\
\hline Pond Da,
\end{tabular}

Fonte: Dados de 2000, IMF (2005); a partir de 2001, IMF (2006).

No mais, um outro fator, de ordem institucional, que atua no sentido de reforçar a importância do componente custo de oportunidade do spread bancário, por tornar ainda mais atraentes os títulos públicos para os bancos, corresponde aos efeitos acarretados pelos limites às operações de empréstimos impostos pelo Acordo da Basiléia, a que o Brasil aderiu em agosto de $1994 .{ }^{40}$ Com o propósito de minimizar os riscos associados à atividade bancária e diminuir as diferenças de regulação do crédito entre os países, o Acordo da Basiléia estabelece um nível mínimo de capital às operações ativas dos bancos (razão capital-ativo), ${ }^{41} \mathrm{o}$ inverso da alavancagem ${ }^{42}$ (Soares, 2001).

(40) Resolução n. 2.099, de 26 de agosto de 1994, do Banco Central do Brasil.

(41) Visando, grosso modo, a maior solidez do sistema financeiro.

(42) O acordo recomenda uma alavancagem 12,5 vezes do patrimônio líquido para os países signatários, o que implica um capital mínimo de $8 \%(1 / 12,5)$. Ou seja, para cada R\$ 100 de ativos, o banco necessita manter $\mathrm{R} \$ 8$ de capital, sendo o restante ( $\mathrm{R} \$ 92)$ financiado por recursos de terceiros. Esse limite é ponderado pelo risco de cada categoria de operação ativa, de modo que o capital que o banco deve ter - Patrimônio Líquido Exigível (PLE) - pode ser determinado pelo capital mínimo multiplicado pelo total do ativo ponderado pelo risco. Nesse sentido, enquanto o capital mínimo exigido em operações ativas mais arriscadas, como empréstimos e financiamentos, mostra-se sujeito à ponderação de $100 \%$, isto é, para cada R $\$ 100$ emprestados, o banco deve ter R\$ 8 de capital, algumas operações, como aquisição de títulos públicos federais, são sujeitas a peso zero (risco nulo), ou seja, para cada R\$ 100 destinados à aquisição de tais papéis, o banco não necessita de nenhum capital. Isso é o que o referido acordo recomenda, sendo que os países signatários podem atribuir um nível de capital mínimo maior, como no caso brasileiro. Embora quando da adoção das prescrições do Acordo, o capital mínimo exigido fosse de $8 \%$ ponderado pelo risco do ativo do banco, a partir de 1997 esse percentual foi elevado para 11\% - Circular 2.784, de 27 de novembro de 1997, do Banco Central do Brasil. Doravante, a capacidade de alavancagem dos bancos foi reduzida, mais precisamente de 12,5 para 9,09 vezes o patrimônio líquido (Soares, 2001). 
A exigência de capital mínimo para as operações de crédito ante a nãoexigência para as operações com títulos públicos faz com que os papéis do governo federal se tornem ainda mais atrativos para os bancos no país. Essa condição, de acordo com o BID (2005, p. 98), atua no sentido de induzir “[...] os bancos a procurar títulos da dívida pública [...]". ${ }^{43}$ Logo, ao se traduzir em mais um custo (implícito) à operação de crédito, a exigência de capital mínimo se traduz num importante condicionante da política de aplicações do banco. Nas palavras de Soares (2001, p. 34):

O banco ao reduzir o volume de crédito diminui a razão lucro-capital. Porém, a queda da lucratividade pode não ser suficiente para forçar o banco a aumentar o seu patrimônio líquido, desde que possa aumentar as aplicações em títulos públicos federais e recompor a sua margem de lucro. Assim, o banco que optar pela manutenção do capital, pela redução do crédito e pelo aumento da carteira de títulos federais, possivelmente, apresentará aos seus depositantes e acionistas um índice de lucratividade maior do que o banco que optar pelo aumento do patrimônio líquido para manter o nível de crédito.

Nessa perspectiva, a exigência de capital mínimo para as operações de crédito, quando não se exige requerimento mínimo de capital para outras operações atrativas, como os títulos da dívida pública, faz com que os bancos privilegiem aplicações com pequena ou nula ponderação de risco, cobrando um prêmio adicional em operações de elevada ponderação, como os empréstimos. De acordo com Soares (2001, p. 39), "o impacto negativo da adesão do Brasil ao Acordo da Basiléia foi o de estabelecer um limite para o crédito e não estabelecer limite para as aplicações em títulos públicos federais".

Embora a análise dos "Índices da Basiléia" dos dez maiores bancos do país no período 2001-2005 (Tabela 6), hierarquizados pelo tamanho do ativo de cada banco na posição de junho de 2005, mostre que há espaço para o aumento de crédito sem a necessidade de elevação do nível de capital próprio dessas instituições, mostra-se razoável supor que essas instituições cobram em suas operações de empréstimos um prêmio pela necessidade de capital próprio para a realização da operação, mesmo havendo "folga" para aumentar empréstimos sem elevar o patrimônio. Isso ocorre porque a necessidade de capital próprio atua no sentido de limitar a capacidade operacional destas instituições para fazer frente a oportunidades de lucro percebidas. Isso indica que os efeitos gerados pelo custo alternativo dos empréstimos sobre o spread bancário são potencializados pela exigência de capital mínimo estabelecida para as operações de crédito. A

(43) Ainda de acordo com o BID (2005, p. 98), a elevada participação dos títulos da dívida pública no ativo dos bancos atua no sentido de fragilizar essas instituições, uma vez que em momentos de crise o risco de default do governo tende a aumentar. Característica comum aos países da América Latina, exceto Chile e Equador, a atribuição de risco nulo às aplicações em títulos públicos acaba vulnerabilizando os sistemas bancários da região em relação aos choques negativos que atingem a economia (BID, 2005). 
atribuição de risco nulo às aplicações dos bancos em títulos públicos federais num contexto de altas taxas de juros básicas funciona como um desestímulo à concessão de empréstimos, criando anomalias no mercado de crédito.

Tabela 6

Índice da Basiléia dos dez maiores bancos no país, em \%: classificação por tamanho do ativo na posição de dezembro de 2005 (2001-2005)

\begin{tabular}{|c|c|c|c|c|c|}
\hline Instituições & 2001 & 2002 & 2003 & 2004 & 2005 \\
\hline Banco do Brasil $^{\text {(a) }}$ & 12,61 & 12,24 & 13,65 & 15,14 & 17,06 \\
\hline $\mathrm{CEF}^{(\mathrm{b})}$ & 13,56 & 14,68 & 19,24 & 20,27 & 27,87 \\
\hline Bradesco $^{\text {(a) }}$ & 15,22 & 17,89 & 19,85 & 18,75 & 17,26 \\
\hline Itaú $^{\text {(a) }}$ & 18,27 & 17,05 & 20,22 & 20,06 & 16,66 \\
\hline Unibanco $^{\text {(a) }}$ & 13,72 & 15,71 & 18,60 & 16,27 & 15,64 \\
\hline Santander Banespa ${ }^{\text {(a) }}$ & 14,66 & 15,09 & 18,08 & 16,96 & 14,13 \\
\hline $\mathrm{ABN} \mathrm{AMRO}^{\text {(a) }}$ & 16,75 & 15,73 & 19,55 & 19,34 & 15,19 \\
\hline Safra ${ }^{(a)}$ & 12,91 & 16,69 & 15,59 & 15,44 & 13,08 \\
\hline $\mathrm{HSBC}^{(a)}$ & 12,23 & 12,93 & 14,39 & 13,95 & 14,33 \\
\hline Votorantim & 12,27 & 19,57 & 22,12 & 17,47 & 15,93 \\
\hline Média & 14,22 & 15,76 & 18,13 & 17,37 & 17,06 \\
\hline Part. no setor bancário & 60,83 & 64,53 & 79,46 & 79,16 & 27,87 \\
\hline
\end{tabular}

Nota: (a) refere-se ao conglomerado: conjunto de instituições financeiras que consolidam seus demonstrativos contábeis; (b) refere-se a Instituição Bancária Independente: instituições financeiras do tipo banco comercial, banco múltiplo com carteira comercial ou caixa econômica que não integrem conglomerado.

Fonte: Adaptado de Banco Central do Brasil (01 nov. 2006).

Finalmente, cumpre esclarecer que o custo alternativo das operações de crédito no Brasil, representado pela atratividade em termos de rentabilidade e liquidez dos títulos públicos federais, e que dá origem ao componente "custo de oportunidade" do spread bancário no Brasil, não está relacionado ao conceito de "efeito deslocamento", a partir do qual os bancos dirigiriam seus recursos ao financiamento do governo em detrimento das operações de crédito ao setor privado, como se a quantidade de recursos que o banco dispõe fosse determinada ex ante. Em vez disso, a hipótese aqui sustentada encontra-se em sintonia com o referencial pós-keynesiano, de acordo com o qual os bancos, antes de aplicarem seus recursos, farão uma análise comparativa da relação entre retornos monetários e não monetários de todos os ativos existentes na economia, e cuja carteira de ativos irá depender de suas expectativas em relação a um futuro incerto.

Significa dizer, pois, que os bancos não ficam "incapacitados" de realizar operações de crédito por aplicarem seus recursos em títulos públicos. Ao contrário, empréstimos serão concedidos todas as vezes que os mutuários atenderem às exigências dos bancos, nem que para tanto precisem escapar de restrições impostas pela autoridade monetária. A restrição à oferta de crédito ocorre porque na presença de ativos líquidos, seguros e rentáveis no mercado, as exigências dos bancos serão muito grandes, especialmente em termos da margem 
cobrada nos empréstimos, mas também sob a forma de garantias exigidas dos mutuários, pois o retorno mínimo exigido para as operações de crédito é representado pela taxa básica de juros da economia, no Brasil excepcionalmente elevada. Embora rendam menos que os empréstimos, os títulos públicos permitem a manutenção de uma postura operacional rentável e reativa a novas oportunidades de lucro para essas instituições. De acordo com Carvalho (2005, p. 384), "a questão não é de um crowding out do setor privado pelo setor público, de 'expulsão' do setor privado, mas sim de atrofia das relações de crédito e da alavancagem financeira da economia devido à política de juros elevados e à persistente atitude defensiva das grandes empresas e dos bancos".

Por fim, convém ressaltar que embora representativo, o componente "custo de oportunidade" do spread bancário no Brasil não deve ser absolutizado no sentido de cumprir o papel de explicação geral para as elevadas margens cobradas pelos bancos no Brasil. Fatores institucionais, microeconômicos e outros macroeconômicos também influenciam os diferenciais cobrados pelos bancos entre as suas taxas de aplicação e captação de recursos. Procurou-se aqui chamar a atenção a um fator pouco ou simplesmente não considerado na grande parte dos estudos sobre o tema, notadamente nos estudos realizados pela autoridade monetária. Enquanto estas instituições tiverem a possibilidade de aplicar seus recursos em ativos seguros, líquidos e altamente rentáveis, condição que implica minimização do trade-off retorno versus liquidez, o prêmio de risco envolvido nas operações de crédito tenderá a permanecer em patamar muito alto no país, reprimindo o mercado de crédito doméstico e obstaculizando a retomada do crescimento econômico sustentado.

\section{Conclusão}

A abordagem pós-keynesiana sobre o comportamento dos bancos mostra que, antes de aplicar seus recursos, essas instituições fazem uma análise comparativa da taxa própria de juros de todos os ativos existentes na economia. Logo, a composição do seu portfólio de aplicações fica na dependência de suas expectativas em relação a um futuro incerto, tanto no que diz respeito à capacidade de pagamento do mutuário no período vindouro, quanto ao cumprimento das cláusulas constantes na peça contratual, especialmente a posse das garantias oferecidas para cobrir o risco de inadimplência.

O artigo discutiu o chamado componente "custo de oportunidade" do spread bancário no Brasil. Sustentou-se que a prática de elevada taxa básica de juros implica aumento do spread bancário não somente pelo fato de aumentar o risco de inadimplência envolvido nas operações de empréstimos, conforme convencionalmente admitido pelos estudos realizados sobre o tema, mas também por elevar o custo de oportunidade dessas operações. Por apresentarem elevados 
retornos monetários e não monetários, os títulos públicos se tornam muito convidativos para os bancos, pois permitem a manutenção de uma estrutura operacional simultaneamente flexível e rentável para essas instituições. Nesse sentido, deduz-se que a redução da taxa básica de juros da economia constitui elemento indispensável para a queda pronunciada das margens cobradas pelos bancos em seus empréstimos no Brasil.

Cumpre reiterar, ainda, que não se pretende minimizar a importância dos demais fatores explicativos do elevado spread bancário no país. Buscou-se apenas lançar luz a mais um componente que ajuda a explicar as altas margens cobradas pelos bancos em suas operações de empréstimos, cujo grau de importância irá variar de acordo com a especificidade de cada modalidade de crédito. Nessa perspectiva, mostra-se importante a realização de estudos que incorporem a taxa básica de juros no conjunto de fatores explicativos do spread bancário no Brasil, preferencialmente a partir de métodos que façam uso de pressupostos teóricos mais condignos ao comportamento dos bancos no mundo real.

\section{Referências bibliográficas}

AFANASIEFF, Tarsila Segalla; LHACER, Priscilla Maria Villa; NAKANE, Márcio I. The determinants of bank interest spread in Brazil. Brasília, DF: Banco Central do Brasil, 2002. 31p. (Working Papers Series, n. 46). Disponível em: $<$ http://www.bcb.gov.br/pec/wps/port/default.asp?idioma=P\&id=TRABDISCLISTA $>$. Acesso em: 10 maio 2003.

ANDIMA. O novo perfil do sistema financeiro. Rio de Janeiro, 2001.

BANCO CENTRAL DO BRASIL. 50 maiores bancos e o consolidado do sistema financeiro nacional. Disponível em: <http://www.bcb.gov.br/fis/top50/port/default.asp? parmidioma=P\&id=TOP50>. Acesso em: 01 nov. 2006.

Séries temporais. Disponível em: http://www.bcb.gov.br /?SERIETEMP>. Acesso em: 05 fev. 2006.

Relatório anual 2005. Brasília, DF, 2005a. p. 43-67. Disponível em: <http://www.bcb.gov.br/? BOLETIM2005>. Acesso em: 28 jun. 2006.

Relatório de economia bancária e crédito. Brasília, DF, 2005b. p. 9-28. Disponível em: <http://www.bcb.gov.br/?SPREAD>. Acesso em: 01 out. 2006.

BANCO CENTRAL DO BRASIL. Economia bancária e crédito: avaliação de 5 anos do projeto juros e spread bancário. Brasília, DF, 2004. p. 5-16. Disponível em: $<$ http://www.bcb.gov.br/?SPREAD>. Acesso em: 10 jun. 2005.

Economia bancária e crédito: avaliação de 4 anos do projeto juros e spread

bancário. Brasília, DF, 2003. p. 8-22. Disponível em: < http://www.bcb.gov.br/?SPREAD>. Acesso em: 10 jan. 2004. 
BANCO CENTRAL DO BRASIL. Economia bancária e crédito: avaliação de 3 anos do projeto juros e spread bancário. Brasília, DF, 2002. p. 3-36. Disponível em: $<$ http://www.bcb.gov.br/?SPREAD>. Acesso em: 10 jan. 2003.

Juros e spread bancário no Brasil: avaliação de 2 anos do projeto. Brasília, DF, 2001. p. 3-14, 49-57. Disponível em: <http://www.bcb.gov.br/?SPREAD>. Acesso em: 10 jan. 2003.

Juros e spread bancário no Brasil. Brasília, DF, 1999. p. 3-28. Disponível em: $<$ http://www.bcb.gov.br/?SPREAD>. Acesso em: 10 jan. 2003.

BARROS, José R. M. de; LOYOLA, Gustavo J. L.; BOGDANSKI, Joel. Reestruturação do setor financeiro. Brasília, DF: Banco Central do Brasil, 1998.

BID. Libertar o crédito: como aprofundar e estabilizar o financiamento bancário. Rio de Janeiro: Elsevier, 2005. p. 3-26, 89-102.

CARVALHO, Carlos Eduardo. Dívida pública: um debate necessário. In: SICSÚ, João; PAULO, Liz Fernando R. de; MICHEL, Renaut. Novo-desenvolvimentismo: um projeto nacional de crescimento com equiidade social. Barueri: Manole; Rio de Janeiro: Fundação Konrad Adenauer, 2005. p. 379-399.

CARVALHO, Fernando J. Cardim de. O sistema financeiro brasileiro: a modernização necessária. In: SICSÚ, João; PAULO, Liz Fernando R. de; MICHEL, Renaut. Novodesenvolvimentismo: um projeto nacional de crescimento com eqüidade social. Barueri: Manole; Rio de Janeiro: Fundação Konrad Adenauer, 2005. p. 329-346.

Sistema financeiro, crescimento e inclusão. Rio de Janeiro: IE/UFRJ, 2003. Versão preliminar apresentada no ciclo de seminários 2003: Brasil em desenvolvimento, realizado no Rio de Janeiro entre set. e nov. Disponível em: $<$ http://www.ie.ufrj.br/desenvolvimento/papers.php>. Acesso em: 20 out. 2003.

. On banks' liquidity preference. In: DAVIDSON, Paul; KREGEL, Jean (Ed.). Full employment and price stability in a global economy. Cheltenham: Edward Elgar, 1999. Mimeografado.

Economia monetária e financeira: teoria e prática. Rio de Janeiro: Campus, 2000. p. 1-15, 41-59, 252-273.

CHU, Victorio Yi Tson; NAKANE, Márcio I. Por que a taxa de juros do cheque especial é tão alta. In: BANCO CENTRAL DO BRASIL. Economia bancária e crédito: avaliação de 5 anos do projeto juros e spread bancário. Brasília, DF, 2004. p. 5-16. Disponível em: $<$ http://www.bcb.gov.br/?SPREAD $>$. Acesso em: 01 ago. 2005. p. 81-89.

COSTA, Ana Carla Abrão; NAKANE, Márcio I. A decomposição do spread bancário no Brasil. In: BANCO CENTRAL DO BRASIL. Economia bancária e crédito: avaliação de 5 anos do projeto juros e spread bancário. Brasília, DF, 2004. p. 5-16. Disponível em: $<$ http://www.bcb.gov.br/?SPREAD>. Acesso em: 01 ago. 2005. p. 17-30.

FACHADA, Pedro; FIGUEIREDO, Luiz Fernando; LUNDBERG, Eduardo. Sistema judicial e mercado de crédito no Brasil. Notas Técnicas do Banco Central do Brasil, Brasília, n. 35, maio 2003. Disponível em: <http://www.bcb.gov.br/?NOTASTEC $>$. Acesso em: $10 \mathrm{abr}, 2003$. 
FREITAS, Maria Cristina P. de. Política financeira, fragilidade e reestruturação bancária. In: CARNEIRO, Ricardo et al. Gestão estatal no Brasil: armadilhas da estabilização 19951998. São Paulo: Fundap, 2000. p. 237-295.

Moeda endógena e passividade bancária: uma análise crítica da abordagem "horizontalista" e da teoria do circuito monetário. Revista de Economia Política, São Paulo, v. 19, n. 4, p. 114-133, out./dez. 1999.

FUENTES, Rodrigo; BASCH, Miguel. Macroeconomic influences on bank spreads in Chile, 1990-95. In: BROCK, Philip; ROJAS-SUÁREZ, Liliana (Ed.). Why so high? understanding interest rate spreads in Latin America. Washington: Inter-American Development Bank, 2000. p. 117-151.

GRC VISÃO. Ranking juros reais - setembro 2005. Disponível em: $<$ http://www.globalinvest.com.br/grcvisao/tipos_relatorios.asp?strTipoProduto=1\&strIdTi poRelatorio $=88>$. Acesso em: 18 set. 2005.

IBGE. Sistema financeiro: uma análise a partir das contas nacionais 1990-1995. Rio de Janeiro, 1997.

INTERNATIONAL MONETARY FUND. Global financial stability report. Washington, Sept. 2006. Disponível em: <http://www.imf.org/external/pubs/ft/GFSR/2006/02/ index.htm>. Acesso em: 01 nov. 2006.

. Global financial stability report. Washington, Apr. 2005. Disponível em: $<$ http://www.imf.org/External/Pubs/FT/GFSR/2005/01/index.htm> Acesso em: 01 set. 2005 .

. International financial statistics. Washington, Sept. 2006.

KEYNES, J. M. (1936). A teoria geral do emprego, do juro e da moeda. 3. ed. São Paulo: Nova Cultural, 1985. (Os economistas). Primeira edição em inglês, 1936.

. (1930a). A treatise on money: the applied theory of money. In: ROYAL ECONOMIC SOCIETY. The collected writings of John Maynard Keynes. New York: Cambridge University Press, 1971. v. VI. p. 43-69, 217-230. Primeira edição em inglês, 1930 .

(1930b). A treatise on money: the pure theory of money. In: ROYAL ECONOMIC SOCIETY. The collected writings of John Maynard Keynes. New York: Cambridge University Press, 1971. v. V. p. 3-43, 217-230. Primeira edição em inglês, 1930.

LAEVEN, Luc; MAJNONI, Giovanni. Does judicial efficiency lower the cost of credit? [Washington]: World Bank, 2003. 34p. (World Bank Policy Research Working Paper, n. 3159). Disponível em: <http://econ.worldbank.org/resource.php >. Acesso em: 01 nov. 2003.

NAKANE, Márcio I. Concorrência e spread bancário: uma revisão da evidência para o Brasil. In: BANCO CENTRAL DO BRASIL. Economia bancária e crédito: avaliação de 4 anos do projeto juros e spread bancário. Brasília, DF, 2003. p. 58-67. Disponível em: <http://www.bcb.gov.br/?RED-SPREAD>. Acesso em: 10 jan. 2004.

; COSTA, Ana Carla A. Spread bancário: os problemas da comparação internacional. In: BANCO CENTRAL DO BRASIL. Relatório de economia bancária e 
crédito. Brasília, DF, 2005. p. 59-68. Disponível em: <http://www.bcb.gov.br/?SPREAD>. Acesso em: 01 out. 2006.

OLIVEIRA, Giuliano Contento de. Análise do spread bancário no Brasil após o Plano Real (1994-2003). 2004. 122f. Dissertação (Mestrado em Economia)-Programa de Estudos Pós-Graduados em Economia Política da Pontifícia Universidade Católica de São Paulo, PUC/SP, São Paulo, 2004.

; CARVALHO, Carlos Eduardo. Spread bancário no Brasil: desafio e dilemas. Revista de Conjuntura do Corecon/DF, Brasília, DF, ano IV, n. 16, p. 11-17, out./dez. 2003.

ONO, F. H.; COSTA DA SILVA, G. J.; OREIRO, J. L.; PAULA, L. F. de. Spread bancário no Brasil: determinantes e proposições de políticas. In: SICSÚ, João; PAULO, Liz Fernando R. de; MICHEL, Renaut. Novo-desenvolvimentismo: um projeto nacional de crescimento com eqüidade social. B arueri: Manole; Rio de Janeiro: Fundação Konrad Adenauer, 2005. p. 347-378.

PAULA, Luiz Fernando R. de. Abrindo a caixa-preta do "spread". Folha de S. Paulo, São Paulo, 29 nov. 2003. Folha Brasil, Caderno 1, p. 3.

; ALVES JR., Antonio José. Banking behaviour and the Brazilian economy after the Real Plan: a post-keynesian approach. Banca Nazionale del Lavoro Quarterly Review, Roma, v. LVI, n. 227, p. 337-365, Dec. 2003.

; ALVES JR., Antonio José; MARQUES, Maria Beatriz Leme. Ajuste patrimonial e padrão de rentabilidade dos bancos privados no Brasil durante o Plano Real (1994/98). Estudos Econômicos, São Paulo, v. 31, n. 2, p. 285-310, abr./jul. 2001.

PINHEIRO, Armando Castelar. O componente judicial dos spreads bancários. In: BANCO CENTRAL DO BRASIL. Economia bancária e crédito: avaliação de 4 anos do projeto juros e spread bancário. Brasília, DF, 2003. p. 34-43. Disponível em: $<$ http://www.bcb.gov.br/?RED -SPREAD>. Acesso em: 10 jan. 2004.

SHARPE, Steven A. Asymmetric information, bank lending, and implicit contracts: a stylized model of customer relationships. The Journal of Finance, New York, v. XLV, n. 4, p. 1069-1087, Sept. 1990.

SOARES, Ricardo Pereira. Evolução do crédito de 1994 a 1999: uma explicação. Brasília, DF: Ipea, 2001. 46 p. (Texto para Discussão, n. 808). Disponível em: $<$ http://www.ipea.gov. br/>. Acesso em: 01 jun. 2002.

TAKEDA, Tony. O canal de crédito no Brasil através dos balanços patrimoniais bancários. 2003. 89f. Dissertação (Mestrado em Economia)-Faculdade de Economia, Administração e Contabilidade da Universidade de São Paulo, FEA/USP, São Paulo, 2003. 